\title{
Modifications in Gene Expression in the Process of Osteoblastic Differentiation of Multipotent Bone Marrow-Derived Human Mesenchymal Stem Cells Induced by a Novel Osteoinductive Porous Medical-Grade 3D-Printed Poly( $\varepsilon$-caprolactone)/ $\beta$-tricalcium Phosphate Composite
}

\author{
Ivan López-González ${ }^{1, *,+(\mathbb{D})}$, Camilo Zamora-Ledezma ${ }^{1,+}{ }^{(D}$, María Isabel Sanchez-Lorencio ${ }^{2}$, \\ Elena Tristante Barrenechea ${ }^{3}$, José Antonio Gabaldón-Hernández ${ }^{4}$ (D) and Luis Meseguer-Olmo ${ }^{1, *, t}$ (D)
}

Citation: López-González, I.; Zamora-Ledezma, C.; Sanchez-Lorencio, M.I.; Tristante Barrenechea, E.; Gabaldón-Hernández, J.A.; Meseguer-Olmo, L. Modifications in Gene Expression in the Process of Osteoblastic Differentiation of Multipotent Bone Marrow-Derived Human Mesenchymal Stem Cells Induced by a Novel Osteoinductive Porous Medical-Grade 3D-Printed Poly ( $\varepsilon$-caprolactone) $/ \beta$-tricalcium Phosphate Composite. Int. J. Mol. Sci. 2021, 22, 11216. https://doi.org/ 10.3390/ijms222011216

Academic Editors: Antonella Forlino and Pierre Moffatt

Received: 15 September 2021

Accepted: 15 October 2021

Published: 18 October 2021

Publisher's Note: MDPI stays neutral with regard to jurisdictional claims in published maps and institutional affiliations.

Copyright: (c) 2021 by the authors. Licensee MDPI, Basel, Switzerland. This article is an open access article distributed under the terms and conditions of the Creative Commons Attribution (CC BY) license (https:// creativecommons.org/licenses/by/ $4.0 /)$
1 Tissue Regeneration and Repair Group, Orthobiology, Biomaterials and Tissue Engineering, Campus de los Jerónimos 135, UCAM-Universidad Católica de Murcia, Guadalupe, 30107 Murcia, Spain; czamora9@ucam.edu

2 Biomedical Research Institute of Murcia (IMIB-Arrixaca-UMU), University Clinical Hospital "Virgen de la Arrixaca", University of Murcia, El Palmar, 30120 Murcia, Spain; msl70082@um.es

3 Plataforma Sala Blanca, IMIB-Arrixaca, Carretera Madrid-Cartagena S/N, El Palmar, 30120 Murcia, Spain; elena.tristante@imib.es

4 Molecular Recognition and Encapsulation Research Group (REM), Health Sciences Department, Campus de los Jerónimos 135, UCAM-Universidad Católica de Murcia, Guadalupe, 30107 Murcia, Spain; jagabaldon@ucam.edu

* Correspondence: ilopez27@ucam.edu (I.L.-G.); lmeseguer@ucam.edu (L.M.-O.); Tel.: +34-968-278-800 (I.L.-G. \& L.M.-O.)

$\dagger$ These authors contributed equally to this work.

\begin{abstract}
In this work, we evaluated the influence of a novel hybrid 3D-printed porous composite scaffold based on poly( $\varepsilon$-caprolactone) (PCL) and $\beta$-tricalcium phosphate $(\beta$-TCP) microparticles in the process of adhesion, proliferation, and osteoblastic differentiation of multipotent adult human bone marrow mesenchymal stem cells (ah-BM-MSCs) cultured under basal and osteogenic conditions. The in vitro biological response of $a$-BM-MSCs seeded on the scaffolds was evaluated in terms of cytotoxicity, adhesion, and proliferation (AlamarBlue Assay ${ }^{\circledR}$ ) after 1, 3, 7, and 14 days of culture. The osteogenic differentiation was assessed by alkaline phosphatase (ALP) activity, mineralization (Alizarin Red Solution, ARS), expression of surface markers (CD73, CD90, and CD105), and reverse transcription-quantitative polymerase chain reaction (qRT-PCR) after 7 and 14 days of culture. The scaffolds tested were found to be bioactive and biocompatible, as demonstrated by their effects on cytotoxicity (viability) and extracellular matrix production. The mineralization and ALP assays revealed that osteogenic differentiation increased in the presence of PCL/ $\beta$-TCP scaffolds. The latter was also confirmed by the gene expression levels of the proteins involved in the ossification process. Our results suggest that similar bio-inspired hybrid composite materials would be excellent candidates for osteoinductive and osteogenic medical-grade scaffolds to support cell proliferation and differentiation for tissue engineering, which warrants future in vivo research.
\end{abstract}

Keywords: 3D printing; poly( $\varepsilon$-caprolactone); $\beta$-tricalcium phosphate; microparticles; composite filament; mesenchymal stem cells; flow cytometry; qRT-PCR; tissue engineering; cell therapies

\section{Introduction}

Nowadays, the most common bone regeneration approaches are focused on the fabrication of affordable substitutes to autologous bone grafts [1-6]. In this context, a large number of strategies have been successfully developed in recent decades, aiming to produce tailored synthetic soft polymer-based biomaterials (which can be administered via injection), rigid scaffolds that act as a 3D framework to mimic bone structures and 
functionalities, or a combination of the aforementioned approaches [1,5,7]. An ideal synthetic matrix in bone regeneration and repair needs to be not only bioactive and resorbable, but also must exhibit specific structural characteristics (micro-/macroporosity), mechanical, and biochemical properties to mimic those from native tissues [8,9], since these properties modulate the biological response of the scaffold and also influence its stiffness, surface morphology, hydrophilicity, degradation, cell adhesion, proliferation, and differentiation [10]. As a matter of fact, an interconnected pore network with open porosity facilitates cell penetration and fluid flow, which also enhances the capacity for cell proliferation [7].

To date, around $60 \%$ of the bone graft substitutes commercially available are based on ceramics. In this sense, different ceramic precursors have been proposed, but the family of calcium phosphate ( $\mathrm{CaP}$ )-based ceramics deserves special attention due to their biocompatibility and unlimited availability [11-14]. Nevertheless, these materials must overcome their main drawback regarding their brittle structure. In addition to ceramicbased substitutes, the most common 3D structured biomaterials are based on natural and synthetic precursors of a different nature, or on their combination [15]. Among the most versatile synthetic polymer precursors for bone graft substitutes, poly( $\varepsilon$-caprolactone) (PCL) deserves special attention due to its biocompatibility, biodegradability, and ductility. Actually, it is widely used for applications in the medical and pharmaceutical industries.

In recent years, a very active branch of materials research based on combining biofriendly polymers with inorganic ceramics such as $\beta$-tricalcium phosphate ( $\beta$-TCP, $\beta$ $\left.\mathrm{Ca}_{3}\left(\mathrm{PO}_{4}\right)_{2}\right)$ has recently flourished, mainly due to their large potential of applications in clinical orthopedics $[13,14,16-21]$. The association of polymers with TCP not only offers the possibility to fabricate tailored materials with enhanced physicochemical properties, but also with modulable resorption rate, facilitating protein/cell adhesion, proliferation, osteogenic differentiation, and osseointegration [22-29]. These materials could also be used as a carrier for the controlled release of various molecules such as growth factors, antibiotics, bisphosphonates, and statins, which would promote the osteogenesis and regeneration of bone tissue $[3-5,9,23,30-35]$. The functionality of the former materials can be exalted by using biological coating additives such as gelatin, chitosan, or fibronectin in order to increase the cell adhesion, avoiding their detachment when they come into contact with organic fluids [36-39]. In this context, Díaz-Arca et al. [2] reported the fabrication of tricalcium phosphate (TCP) and silicocarnotite (SC) scaffolds via sintering, which mimic the internal microstructure of cancellous bones and can be combined with osteogenic factors to improve their performance for bone reconstruction applications [40]. In such materials, the TCP is responsible for releasing calcium and phosphorus ions, thereby enhancing cell proliferation and cellular differentiation [7]. Similarly, Shin et al. [41] reported the fabrication of biphasic PCL/ $\beta$-TCP (BCP) composite scaffolds with an interconnected porous structure via salt-leaching and freeze-drying. They reported that such composite materials permit cell survival, accompanied by a significant osteogenic differentiation. However, they were incapable of observing a significant increase in the proliferation of human mesenchymal stem cells ( $h \mathrm{MSCs}$ ) beyond seven days in culture. Other interesting findings were reported by Park et al. [42], who demonstrated positive osteogenic differentiation of $h \mathrm{MSC}$ under mechanical stimulation of PCL/ $\beta$-TCP 3D-printed scaffolds. Surprisingly, composites with a lower $\beta$-TCP content display lower expression of osteogenic markers if compared to those composites with a higher $\beta$-TCP content. However, they only investigated the effects of $\beta$-TCP on the proliferation and differentiation in vitro for a nine-day period. More recently, Yang et al. [43] reported the biological responses of MC3T3-E1 cell lines on PCL/ $\beta$-TCP 3D-printed scaffolds. They demonstrated that those materials treated by oxygen plasma and/or amine plasma-polymerization positively influence the adhesion, proliferation, and osteogenic differentiation of cells. Thus, the fabrication of alternative bioinspired composite material to stimulate bone regeneration and repair still remains an attractive and open issue. 
In this work, we focus on the fabrication of novel hybrid polymeric-ceramic porous $3 \mathrm{D}$-printed composite scaffolds based on poly ( $\varepsilon$-caprolactone) (PCL) and $\beta$-tricalcium phosphate $(\beta-\mathrm{TCP})$ microparticles, and their influence in the process of adhesion, proliferation, and osteoblastic differentiation of multipotent adult human bone marrow mesenchymal stem cells (ah-BM-MSCs) via primary human mesenchymal stem cell culture. Moreover, we assessed the potential positive influence of the release of calcium and phosphorus ions on metabolic activity and cellular differentiation. We also studied the effects of the physicostructural characteristics of the scaffolds on cytotoxicity (cell viability), extracellular matrix production, and variations in gene expression to confirm osteoblastic differentiation.

\section{Results and Discussion}

\subsection{Study Design}

The first step of the present study was the fabrication of poly( $\varepsilon$-caprolactone) (PCL) $/ \beta$ tricalcium phosphate (PCL/ $\beta$-TCP) 3D-printed porous disk-shaped scaffolds of $8 \times 1.5 \mathrm{~mm}$ (diameter $\times$ height). Subsequently, a detailed characterization of their structure and properties was performed. Three experimental groups were established as follows: (1) Control group or cells growing on polystyrene (TCPS), (2) plates containing PCL scaffolds, and (3) plates containing PCL/ $\beta$-TCP scaffolds. Finally, the in vitro biological behavior was investigated using a primary culture of $a h$-BM-MSCs. All biological studies were carried out according to a previously established schedule (Figure 1).

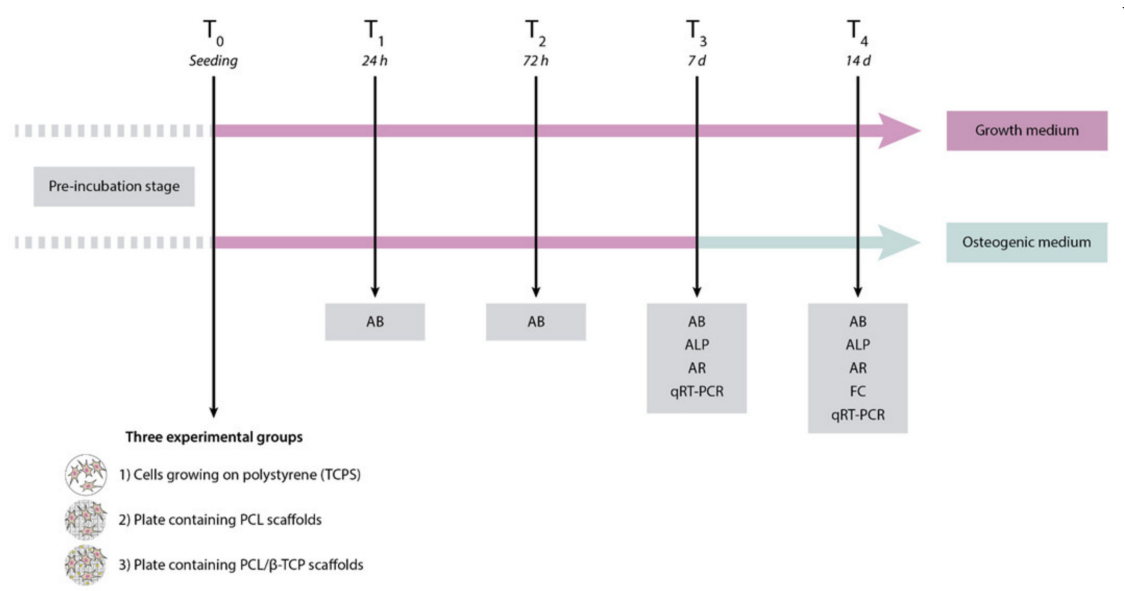

Figure 1. Schematic representation of the study design, including the time schedule of the performed experiments. AB, AlamarBlue assay; ALP, alkaline phosphatase; AR, alizarin red staining; FC, flow cytometry; qRT-PCR, quantitative polymerase chain reaction.

\subsection{Material Composition and Characterization}

2.2.1. Morphological Characterization and Microanalysis of the Composite Filaments and the 3D-Printed Scaffolds

The morphology and diameter of native PCL filaments and PCL/ $\beta$-TCP composite filaments were examined and characterized before being fed into the $3 \mathrm{D}$ bioprinter. As can be seen in the SEM micrographs, the native PCL filaments show a smooth homogeneous surface (Figure S1A), while the PCL/ $\beta$-TCP filaments show a heterogeneous micro-granulated surface due to the presence of $\beta$-TCP microparticles (Figure S1B). Likewise, the $\beta$-TCP coating resulted in a slight increase in the filament diameter from 1.77 to $1.93 \mathrm{~mm}$ (Figure S1C). Additionally, an EDX analysis was carried out on the coated filaments in order to check the presence of phosphorus and calcium elements, obtaining $33.5 \%$ and $66.5 \%$ of the total weight, respectively (Figure S1D,E).

Figure 2A-D show typical non-polarized optical microscopy images for native PCL (Figure 2A,B) and PCL/ $\beta$-TCP (Figure 2C,D) 3D-printed scaffolds. They exhibit a standard disk shape with a diameter of $8 \mathrm{~mm}$ and a height of $1.5 \mathrm{~mm}$. As seen in the magnified microscopies, the printed lines display an ordered structure, adopting a parallel distribution 
in every printed layer (Figure 2B,D). The distance between the scaffold printed lines was $1.30 \pm 0.40 \mathrm{~mm}$ in the vertical and horizontal layers, and $0.35 \pm 0.03 \mathrm{~mm}$ in the diagonal layers, providing a network of interconnected pores of triangular morphology with an average porosity of $200 \mu \mathrm{m}$. We also clearly observed TCP microparticles randomly distributed throughout the entire PCL/ $\beta$-TCP scaffold (Figure $2 \mathrm{C}, \mathrm{D}$ ). Finally, the energy dispersive X-ray (SEM-EDX) microanalysis was performed in order to verify the presence of the TCP mineral fraction. According to our analyses, we obtained a share of $32.25 \%$ and $67.75 \%$ of the total weight of phosphorus and calcium elements, respectively (Figure 2E,F).

A

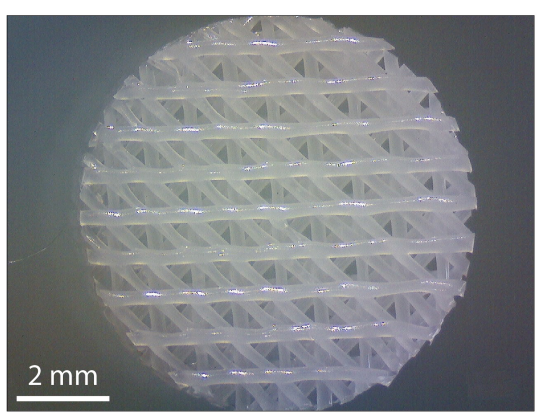

C

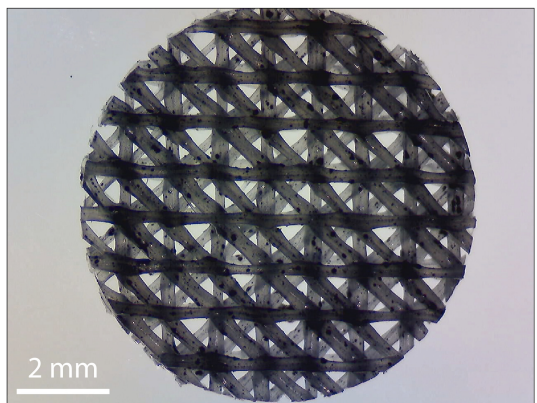

E

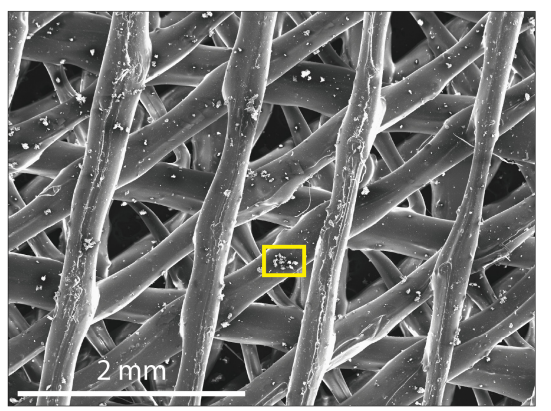

B

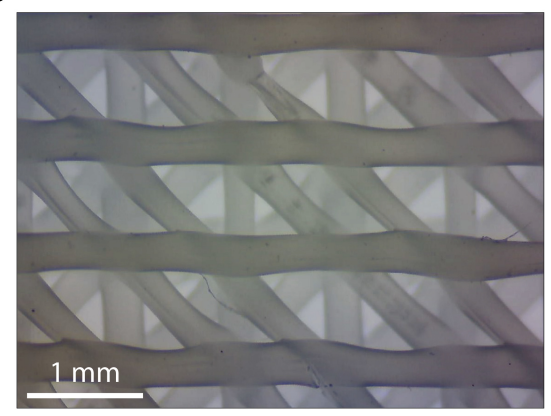

D

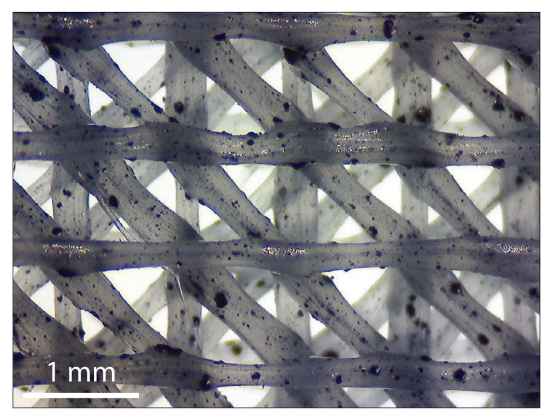

$\mathrm{F}$

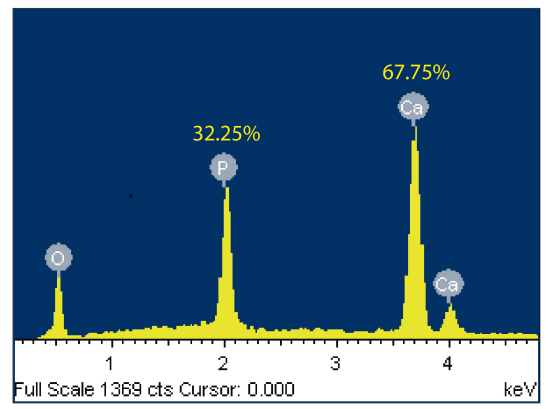

Figure 2. Images of both (A,B) PCL and (C,D) PCL/ $\beta$-TCP scaffolds taken with a stereomicroscope at different magnifications. The $\beta$-TCP microparticles were stained with nigrosine for clarity. (E) Micrograph acquired with SEM showing a magnification of the PCL/ $\beta$-TCP scaffold and (F) its corresponding EDX spectrum. The researched area is depicted as a yellow square.

\subsubsection{Pore Structure Characterization by Micro-CT}

Three-dimensional (3D) printing has emerged as a powerful tool for tissue engineering by enabling 3D cell cultures within complex 3D biomimetic architectures [44]. In contrast to the conventional techniques such as electrospinning [45], freeze-drying [46], gas foaming [47], or fiber deposition [48], 3D printing brings more control to both internal and external scaffold geometry. Parameters such as pore size, total porosity, and pore connectivity play an important role in the mass transport of biological fluids, oxygen, nutrients, and cells from the external environment to the inner parts of the scaffold promoting tissue ingrowth [49]. 
The 3D rendering of the CT images from six randomly selected scaffolds $(n=3$ per sample) showed no statistically significant differences between the volume of both PCL and PCL/ $\beta$-TCP scaffolds (Figure 3). Based on the data collected from 3D reconstructions, both types of scaffolds had an average volume $\left(V_{S}\right)$ of $31 \pm 1 \mathrm{~mm}^{3}$, which corresponds to a global porosity of $0.59 \pm 0.10$ when compared to the theoretical volume $\left(V_{T}=75.4 \mathrm{~mm}^{3}\right)$ of an $8 \times 1.5 \mathrm{~mm}$ (diameter, height) disk.
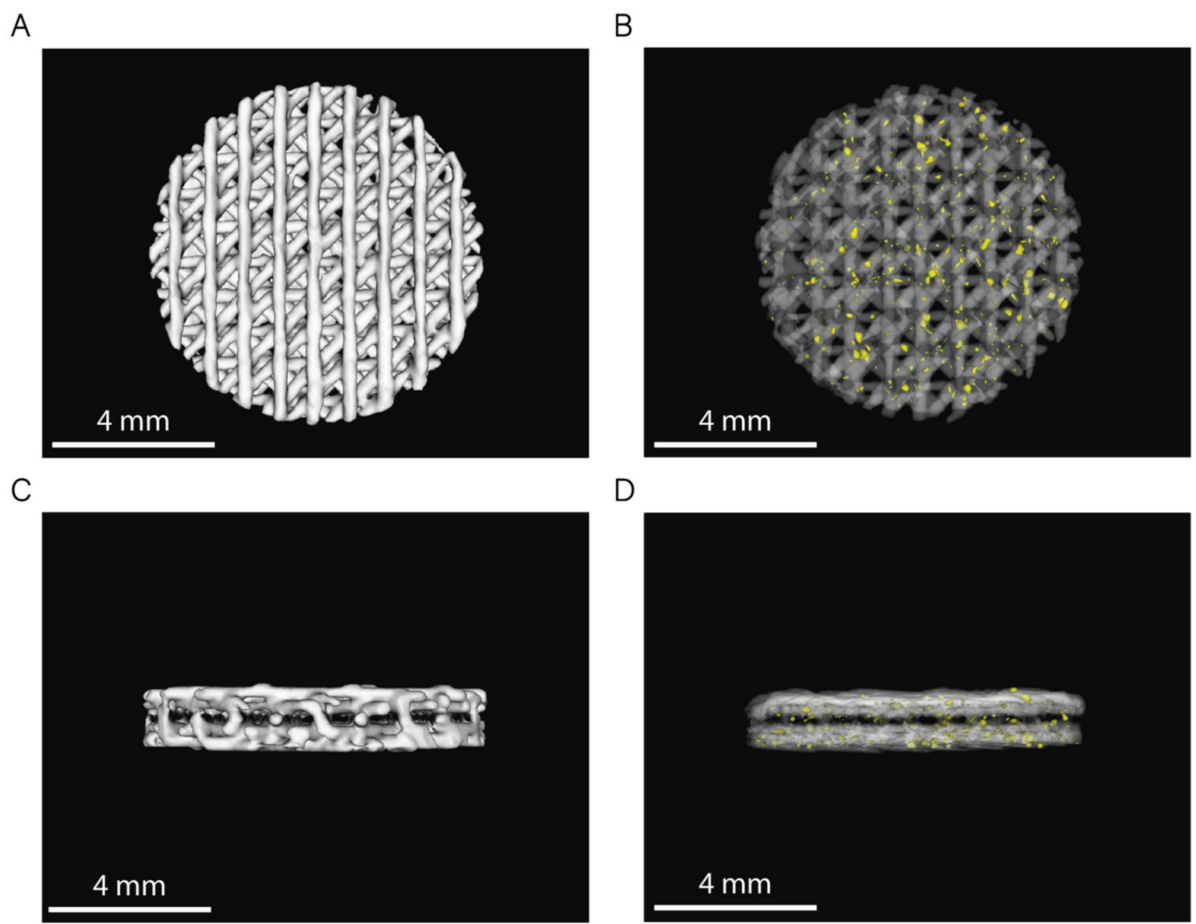

$\mathrm{E}$
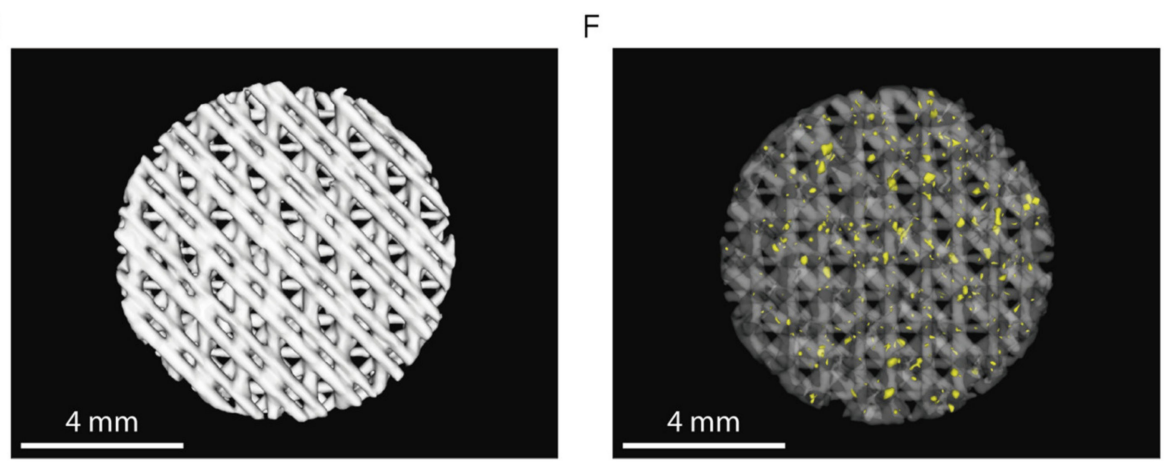

Figure 3. 3D rendering of PCL and PCL/ $\beta$-TCP scaffolds (top: (A,B); lateral: (C,D); and bottom: $(\mathbf{E}, \mathbf{F})$ view). In images $(\mathbf{B}, \mathbf{D}, \mathbf{F}), \mathrm{PCL}$ is shown with $80 \%$ transparency to allow the observation of the $\beta$-TCP particles, which are depicted in yellow.

In order to obtain scaffolds with open and interconnected porosity, we used an $8 \mathrm{~mm}$ biopsy punch to homogenize the samples obtaining scaffolds with an absence of a welldefined peripheral limiting layer. This technical detail allows the peripheral pores on its entire surface to be in direct contact with the external environment. In addition, we selected a triangular infill pattern, which results in a network of interconnected pores.

Finally, the 3D rendering of PCL/ $\beta$-TCP scaffolds (Figure 3B,D,F) showed a random distribution of $\beta$-TCP microparticles over the entire scaffold volume, as outlined in the previous section (Figure 2D). 


\subsection{Influence of the Scaffold Composition}

\subsubsection{Protein Adhesion: Coomassie Brilliant Blue Test}

The Coomassie stain is one of the most widely used assays for protein quantification. As a matter of fact, it provides sensitive protein detection, along with simplified protocols, and it is relatively accurate for most proteins. Besides, it is well known that the contact of a living body with a material induces the absorption of a protein monolayer on its surface, depending on the nature of the material, creating an interface where other proteins and cells adsorb [50]. This protein layer promotes the fact that cell adhesion receptors located on the cell membrane (such as integrins) can recognize the arginine-glycine-aspartate (RGD) peptide, creating anchor points on the surface of the biomaterial [51]. In addition, overall porosity, size, pore distribution, and particle size are factors that also influence the degree of protein adsorption. Thus, the existence of pores greatly increases the surface area of the materials and enhances protein adsorption. In this context, Zhu et al. [52] demonstrated that the amount of total proteins adsorbed by porous $\mathrm{Ca}-\mathrm{P}$ biphasic $\mathrm{Ca}-\mathrm{P}$ porous ceramic (BCP) (HA/TCP 1/4 7:3) was higher than that of dense BCP. Furthermore, once the cells have adhered, the processes of the synthesis and release of the ECM constituent molecules such as osteopontin (OPN), collagen type I (COL1A1), and bone morphogenetic proteins (BMPs), among other regulators of osteogenesis begin $[51,53]$. In other words, the proteins initially adsorbed on the surface and coming from the fluids provide a temporary substrate for cell adhesion.

In our study, the Coomassie Brilliant Blue test-a simple and reliable qualitative procedure-showed that both PCL and PCL/ $\beta$-TCP scaffolds were able to absorb proteins on their surface (Figure 4). The scaffolds that were not submerged in fetal bovine serum (FBS) lost their bluish color after three washes with the destaining solution (Figure 4(2)), while those scaffolds immersed in FBS for 30 min remained blue after the washing step (Figure 4(3)). It is also worth noting that apparently, native PCL scaffolds exhibit a slightly light color if compared to PCL/ $\beta$-TCP after the washing step. The latter is probably due to the presence of $\beta$-TCP microparticles, which would have slightly modified the hydrophobic nature of the surface of PCL making them more hydrophilic, facilitating the proteins adhesion.

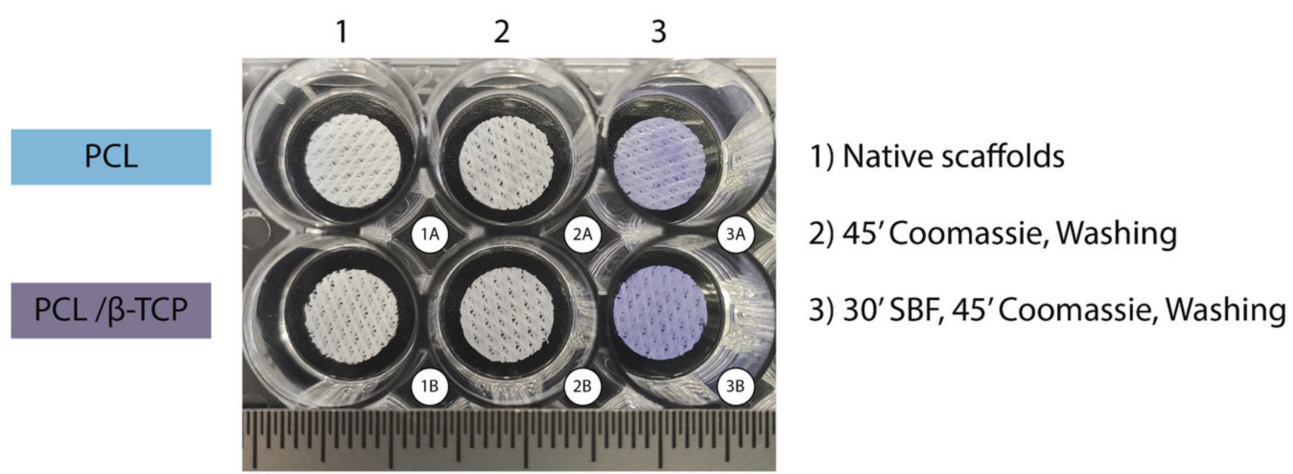

Figure 4. Coomassie Brilliant Blue test performed on PCL (upper row) and PCL/ $\beta$-TCP (bottom row) scaffolds after non-immersion in FBS (2A,B) and 30 min immersion in FBS (3A,B). Two unstained scaffolds were taken as the control $(1 \mathrm{~A}, \mathrm{~B})$.

\subsubsection{In Vitro Degradation Kinetics}

The degradation kinetics of the polymer used for the fabrication of medical-grade composites are of paramount importance. In fact, it is highly desirable to match the polymer biodegradation with their intended functional tissue regeneration use. Typically, degradation is assessed via scaffold immersion in a buffered solution (such as commercially available DMEM or homemade simulated body fluid (SBF) solutions) during periods ranging from days or weeks to months. The scaffold weight loss is directly correlated with the polymer degradation process. PCL is considered a polymer with a very long degradation time. In our case, we immersed at $37^{\circ} \mathrm{C}$ into a biomimetic SBF solution all 
of our PCL and PCL/ $\beta$-TCP scaffolds. The immersion time ranged over 3, 7, 14, 21, and 28 days according to different authors [54,55]. The percentage of the scaffold's weight loss immersed in SBF solutions for various periods of time was then calculated using Equation (2) [56-58]. As expected, for the periods studied, the PCL degradation was less than $1 \%$, even for those exposed during 28 days (data not shown). These results are in total agreement with the expected ones for similar PCL-based composite materials. In fact, as reported by Sukanya et al. [54], the PCL is expected to exhibit weight losses of around 2\% for an extended period of immersion in SBF of 90 days. In spite of the fact that we did not study the TCP degradation, it is worth mentioning that it is widely known from the literature that $\beta$-TCP bioceramics degrade relatively quickly, being able to simultaneously promote new bone formation in vivo [59]. In addition, from a physiological point of view, $\beta$-TCP degrades faster than hydroxyapatite, either via chemical dissolution or via reabsorption by phagocytic cellular mechanisms (macrophages or osteoclasts). The latter would directly affect the bone remodeling process [60].

\subsection{Cell Viability and Proliferation}

\subsection{1. ah-BM-MSC Characterization}

In the present study, ah-BM-MSCs were used to evaluate the biocompatibility and the osteogenic activity of PCL/ $\beta$-TCP scaffolds due to their clinical importance and their great capacity for osteoblastic differentiation [61]. Basically, MSCs have the ability to differentiate ex vivo into various cell lines (such as osteoblast) under favorable environmental conditions [62]. As can be seen in Table 1, the high positive expression of mesenchymal stem cell-like markers, specifically CD73, CD90, CD105, and CD44, was observed in more than $97 \%$ of cells isolated, manifesting its immature phenotype and important regenerative potential and making them suitable for in vitro assays, as reported previously in the literature [63].

Table 1. Flow cytometric analysis for cluster of differentiation (CD) marker expression of $a h$-BMMSCs at passages $3-4 .{ }^{*}$ Hematopoietic markers.

\begin{tabular}{cc}
\hline Antigen & Percentage of Positive Cells \\
\hline CD73 & $99.67 \pm 0.06$ \\
\hline CD90 & $98.27 \pm 0.25$ \\
\hline CD105 & $97.93 \pm 0.06$ \\
\hline CD44 & $97.87 \pm 0.23$ \\
\hline CD14/19/34/45* & $3.10 \pm 0.52$ \\
\hline
\end{tabular}

\subsubsection{Cytotoxicity Assay}

Biocompatibility is one of the most important factors to be taken into account for the fabrication of scaffolds for tissue engineering. In this regard, both PCL and $\beta$-TCP have been previously reported as biocompatible and safe biomaterials [64-66]. Cytotoxicity assays are widely used to measure loss of cellular or intracellular structures and functions, including lethal cytotoxicity levels, providing an unequivocal indication of their potential to cause cell or tissue damage. The cell viability was assessed by using the AlamarBlue assay after seeding $a h$-BM-MSCs on PCL and PCL/ $\beta$-TCP scaffolds (Figure 5). The results of cell viability at 24 and $72 \mathrm{~h}$ after seeding demonstrated that both the PCL and PCL/ $\beta$ TCP scaffolds had no cytotoxic effects on $a$-BM-MSCs. The values of cell viability ranged from $86 \%$ to $114 \%$ for PCL and PCL/ $\beta$-TCP scaffolds at $24 \mathrm{~h}$, and from $88 \%$ to $115 \%$ at $72 \mathrm{~h}$. The mean percentage of viability after direct seeding on both scaffolds was $98 \pm 11$ (PCL) and $100 \pm 10(\mathrm{PCL} / \beta-\mathrm{TCP})$ at $24 \mathrm{~h}$, and $101 \pm 9(\mathrm{PCL})$ and $98 \pm 12(\mathrm{PCL} / \beta-\mathrm{TCP})$ at $72 \mathrm{~h}$. It is also worth noting that no statistically significant differences were observed between the groups. 


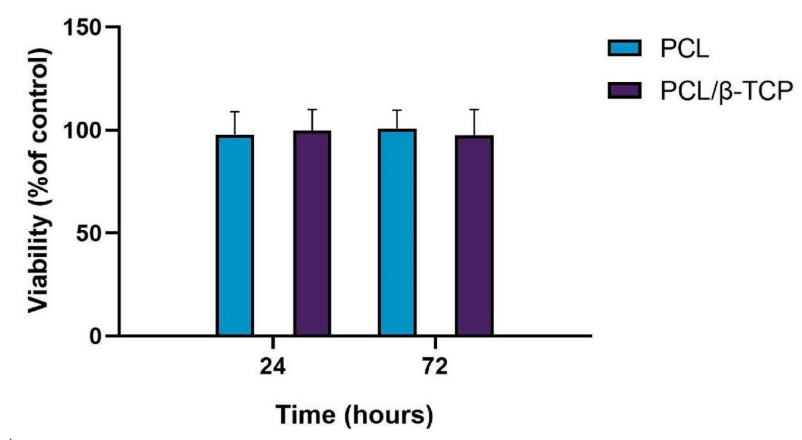

Figure 5. Cell viability using the AlamarBlue assay after 24 and $72 \mathrm{~h}$ of direct seeding of $a h$-BM-MSCs on PCL and PCL/ $\beta$-TCP scaffolds. The mean percentage of viability was calculated and normalized with respect to the viability of cells growing on bare plastic (TCPs) (positive control). Bars represent standard deviations of the mean.

\subsubsection{Cellular Metabolic Activity Assay}

Poly( $\varepsilon$-caprolactone)-based scaffolds have been widely used in recent years for tissue engineering applications due to their biocompatibility, biodegradability, structural stability, and mechanical properties [67]. In this sense, different authors have demonstrated that cells are able to adhere and proliferate onto different PCL-based scaffold structures, such as electrospun fibers [68] and 3D-printed scaffolds [69]. In our work, the hydrophilic properties provided by the coating with the $\beta$-TCP microparticles based on a preliminary wettability test using distilled water (data not shown in this work) may favor adhesion, initial cell growth, and differentiation, since both $a h-B M-M S C s$ and osteoblasts show more affinity toward hydrophilic surfaces [70]. For this reason, the wettability of the scaffold surface was one of the key criteria we took into account when designing this study.

The cellular metabolic activity of $a h$-BM-MSCs grown on both PCL and PCL/ $\beta$-TCP scaffolds was evaluated using the AlamarBlue assay on days 1, 3, 7, and 14 after seeding (Figure 6). The viability of cells growing on scaffolds was normalized with respect to cells growing on plastic (TCPs), which were taken as a positive control. The viability increased gradually for the different time periods studied, indicating that the cells successfully adhered to the scaffolds with a good proliferation rate. It is worth noting that the PCL/ $\beta$ TCP scaffolds showed lower viability than native PCL scaffolds at early periods (days 1 and 3); however, both viability rates were similar at 7 and 14 days of study, either with growth medium (GM) or after the addition of osteogenic medium (OM) on day 7. As clearly shown in the plot, no significant differences were found between scaffolds at these time periods. However, we noted that the addition of OM caused a slight increase in the metabolic activity with respect to those cells seeded on PCL/ $\beta$-TCP scaffolds with GM at 14 days.

\subsection{Cell Differentiation Studies}

\subsubsection{Alkaline Phosphatase (ALP) Activity}

ALP is a hydrolase enzyme responsible for dephosphorylating molecules under alkaline conditions $(\mathrm{pH}>10)$. It is present within all tissues of the body, particularly in bone cells, and is considered an early indicator of osteoblastic differentiation [71]. As widely discussed in the literature, an ALP assay allows establishing a direct relationship between the presence of ALP activity and the normal development of bone in the human body $[72,73]$. 


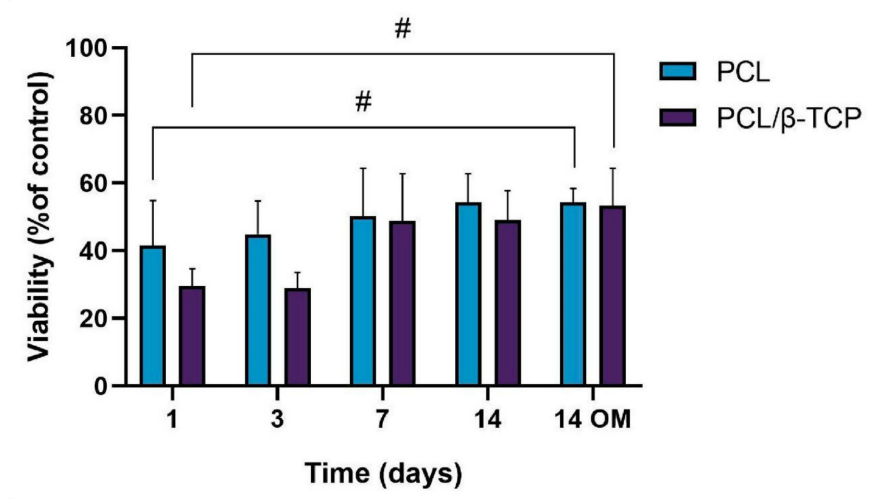

Figure 6. Cellular metabolic activity using the AlamarBlue assay on ah-BM-MSCs seeded on both PCL and PCL/ $\beta$-TCP scaffolds at different time periods. The mean percentage viability was calculated and normalized to the viability of cells growing on plastic (TCPs) (positive control). Bars represent standard deviations of the mean. " Significant differences between the bracketed groups at different time periods.

The ALP activity of cultured ah-BM-MSCs on both PCL and PCL/ $\beta$-TCP scaffolds is shown in Figure 7. From days 7 to 14 (GM), no significant difference in ALP activity was observed between the different time periods or within scaffold types. On the contrary, ALP activity significantly increased from days 7 to $14(\mathrm{OM})$. The maximum ALP activity values were noticed at 14 days in the presence of osteogenic medium (OM) on cells seeded onto PCL/ $\beta$-TCP scaffolds, which reveals that $\beta$-TCP microparticles seem to exert an impact on osteoblastic phenotype and enhance cellular responses. As a matter of fact, previous studies have indicated that the addition of $\beta$-TCP granules into PCL-based composites might enhance the osteoblastic differentiation ability of bone mesenchymal stem cells (BMSCs) [74]. Nevertheless, there still exists a current controversy regarding the time period in which the ALP activity shows its maximum activity. In this context, Chen et al. [75] studied the osteoblastic response of MSCs on hyaluronic acid (HA) / $\beta$-TCP polymeric-based scaffolds. They reported a well-defined peak in ALP activity by day 7 , followed by a decrease, while Jensen et al. [76] reported the maximum ALP activity after 14 days of study in similar polymer-based composites.

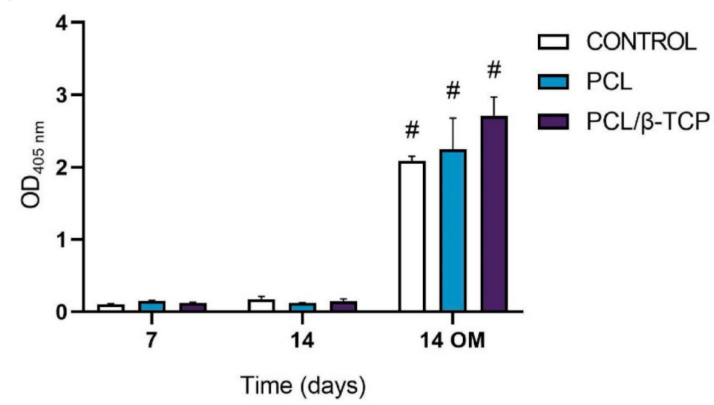

Figure 7. Alkaline phosphatase activity of ah-BM-MSCs seeded on PCL and PCL/ $\beta$-TCP scaffolds after 7 and 14 days of culture. Results are shown as a function of optical density (OD) units. No significant differences were found at the same time periods between the groups. Bars represent standard deviations of the mean. " Significant differences between the marked group at different time periods $(p>0.05)$.

\subsubsection{In Vitro Mineralization. Alizarin Red Solution (ARS) Staining}

Calcium deposition or in vitro mineralization are late markers of osteogenic differentiation. Deposited calcium can be quantified or stained with Alizarin Red Solution (ARS) stain, showing a positive staining (red) of mineralized nodules [77]. The osteogenic effect of the manufactured scaffolds was verified by determining the presence of calcium deposits in the cell culture. For this purpose, the Alizarin Red expression of $a h$-BM-MSCs cultured 
on PCL and PCL/ $\beta$-TCP scaffolds was assessed at 7 and 14 days after seeding (Figure 8). No visual differences were observed after examining the stained samples at different time periods under a contrast phase microscope (data not shown). However, the quantitative examination showed that the Alizarin Red activity of ah-BM-MSCs increased significantly from days 7 to 14 with both growth medium (GM) and osteogenic medium (OM). The addition of $\mathrm{OM}$ promoted a slight increase in the controls at 14 days, but no significant differences were observed between the PCL and PCL/ $\beta$-TCP scaffolds.

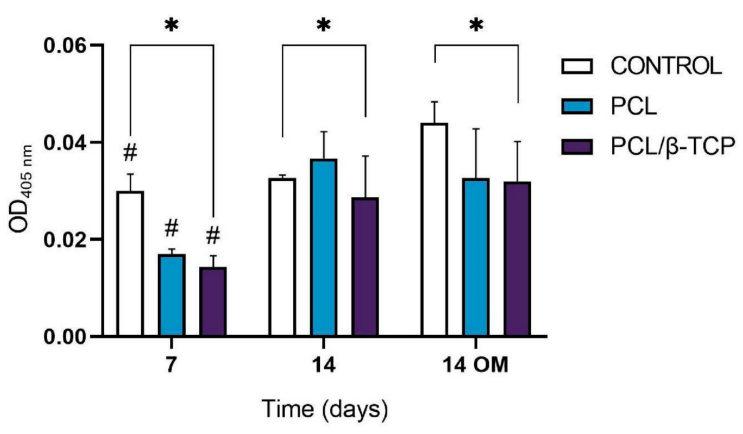

Figure 8. Alizarin Red quantification assay of $a h$-BM-MSCs seeded on PCL and PCL/ $\beta$-TCP scaffolds after 7 and 14 days of culture. Cells seeded on plastic (TCPs) were taken as the positive control. Results are shown as a function of optical density (OD) units. \# Significant differences between the marked group at different time periods $(p>0.05)$. Significant differences between the bracketed groups at the same time period.

\subsubsection{Monitoring Surface Markers on ah-BM-MSCs Seeded on the Scaffolds}

To date, the most commonly reported positive markers related to adult human MSC (ahMSCs) surface are CD105, CD90, CD44, CD73, CD29, CD13, CD34, CD146, CD106, CD54, and CD166 [78]. The minimal criteria of MSCs include: (i) Remaining plasticadherent under standard culture conditions; (ii) expressing CD73, CD90, and CD105; and (iii) differentiating into osteoblasts, adipocytes, and chondrocytes in vitro [79]. The positive expression of the cluster of differentiation markers CD73, CD90, and CD105 of ah-BM-MSCs seeded on both PCL and PCL/ $\beta$-TCP scaffolds is shown in Figure 9. The results are expressed as the percentage of marker lost after 14 days of culture with both GM and OM (added on day 7). As observed, by day 14, the CD73 and CD90 markers' expression decreased significantly after the addition of OM. For both markers, the PCL/ $\beta$ TCP scaffolds showed a higher marker loss than the PCL scaffolds and controls. The higher marker loss throughout the study affected the CD105 marker, whose expression decreased significantly after the addition of OM. In this case, the PCL/ $\beta$-TCP scaffolds showed similar marker loss than the PCL scaffolds. This decrease in the positive expression of the mesenchymal markers (CD73, CD90, and CD105) could be a consequence of the osteogenic differentiation program activation [80].
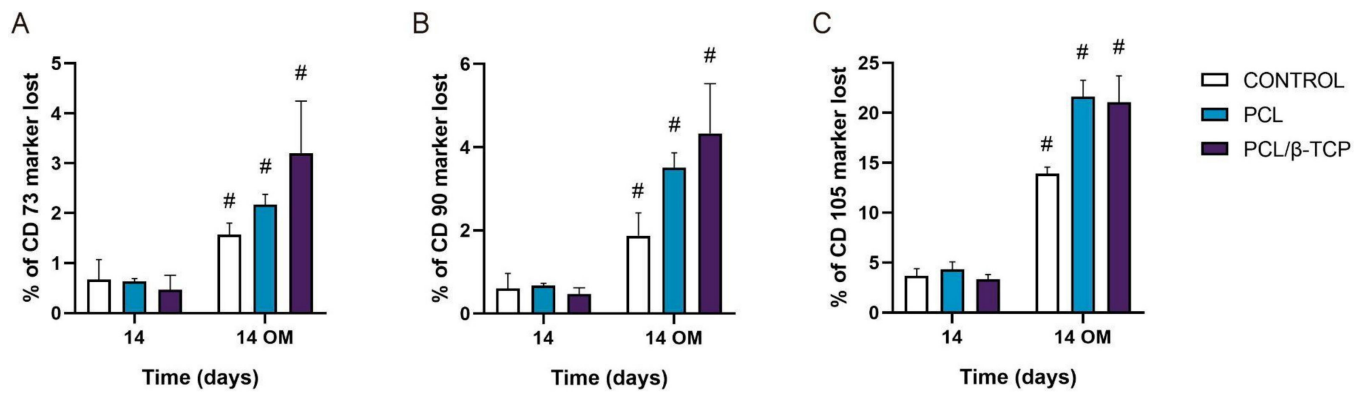

Figure 9. (A) CD73, (B) CD90, and (C) CD105 expressions of the cells seeded on PCL and PCL/ $\beta$-TCP scaffolds. Data represent the percentage of marker loss at 14 days with different culture medium (GM and OM). The experiment was performed in triplicate. \# Significant differences between the marked group with different culture media. 
2.5.4. Osteogenic Gene Expression: Quantitative Real-Time Polymerase Chain Reaction (qRT-PCR) Assay

The gene expression of osteogenic-specific markers such as ALPL, COL1A1, RUNX2, BGLAP, IBSP, SPARC, and SPP1 was used to determine osteoblastic differentiation in vitro by qRT-PCR (Figure 10). As observed, the ALPL marker displayed an increase in gene expression throughout the study, showing higher values after the addition of osteogenic medium $(\mathrm{OM})$ by day 7 . In this time period, the PCL/ $\beta$-TCP scaffolds exhibited higher ALPL gene expression than the PCL scaffolds. For its part, the COL1A1 marker displayed a significant peak in gene expression at 14 days with growth medium (GM). Likewise, the COL1A1 expression with OM increased for the PCL/ $\beta$-TCP scaffolds, with no significant differences in the time periods studied. In the same way, the exhibited RUNX2 gene expression remains almost constant from days 7 to 14 with GM. However, a non-negligible decrease in gene expression was observed by day 14 with OM. The BGLAP gene expression also exhibited almost constant values throughout the study. As a matter of fact, no significant differences were observed between the different time periods. In contrast, the IBSP expression showed a prominent peak on both the PCL and PCL/ $\beta$-TCP scaffolds on day 14 with GM. However, after the addition of OM, an abrupt decrease in IBSP expression was observed. The SPARC gene expression showed higher values in the presence of GM but lower marker expression in the presence of OM. Finally, the SPP1 marker showed a clear decreasing trend from days 7 to 14 with both types of culture media, either GM or OM. It is worth mentioning that in the latter case, the lower expression values were observed on day 14 in the presence of OM.

These results are in total accordance with the results reported by Jensen et al. [76], who studied the influence of PCL scaffolds functionalized with hyaluronic acid and $\beta$-TCP on dental pulp stem cells. In this study, alkaline phosphatase, runt-related transcription factor 2 , bone sialoprotein, and osteopontin markers showed similar trends to those achieved in our work. Similar results were reported by Rabadan-Ros et al. [81], who evaluated the impact of a porous Si-Ca-P monophasic ceramic on osteogenic differentiation of adult human mesenchymal stem cells (ahMSC) in a 28-day study, obtaining an up-regulation of alkaline phosphatase, collagen type I, osteopontin, integrin-binding sialoprotein, and osteonectin expression, while runt-related transcription factor 2 and osteocalcin expression remained relatively unchanged along the assay. Considering the molecules necessary for the mineralization of the extracellular matrix, Runt is defined as a transcription factor in Drosophila, which has affinity with the $\alpha$ subunit of Core Binding Factor Alpha (Cbfa). The three related genes called Core Binding Factor Alpha 1 (Cbfa1), Cbfa2, and Cbfa3 are capable of generating different proteins [82-84]. Cbfa1 (Runx2) is the specific transcription factor for osteogenesis (Runx2/AML3) and the determinant for the differentiation of mesenchymal cells toward osteoblastic lineage [85] under the stimulus of specific genes such as OC, ALP, BSP, collagen type I ( $\mathrm{Col} 1$ ), and Collagenase-3 (matrix metalloproteinase13 (MMP-13) [86].

In this sense, the trend observed in RUNX2 expression in our study and in others analogous could be attributed to the fact that it is involved in multiple signal transduction pathways, and its activity is tightly regulated at both the transcriptional and posttranslational levels [87]. 
A

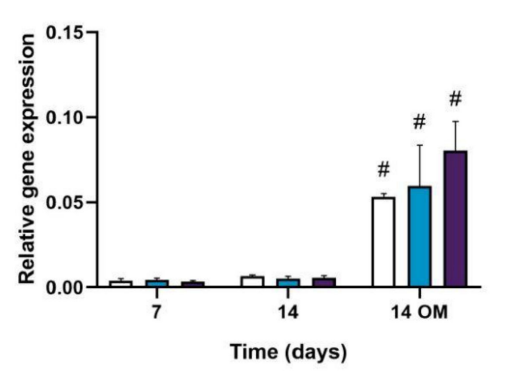

C

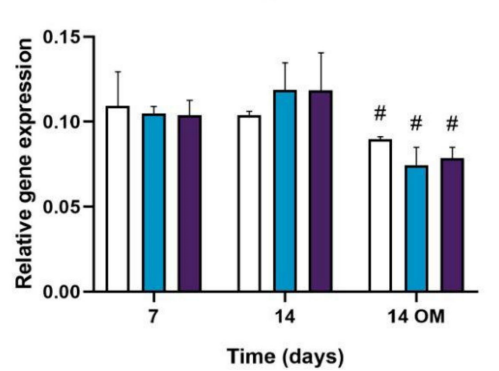

E

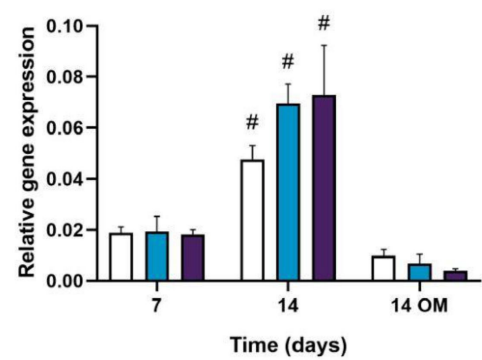

G

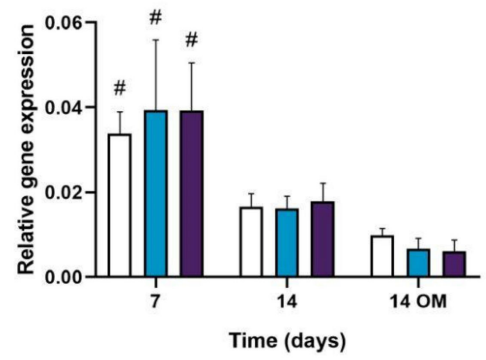

B

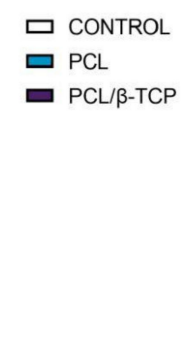

口 CONTROL

$\square \mathrm{PCL}$

PCL/ß-TCP

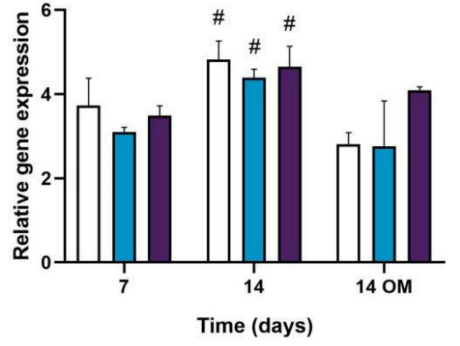

口 CONTROL

$\square \mathrm{PCL}$

- PCL/ß-TCP

D

BGLAP

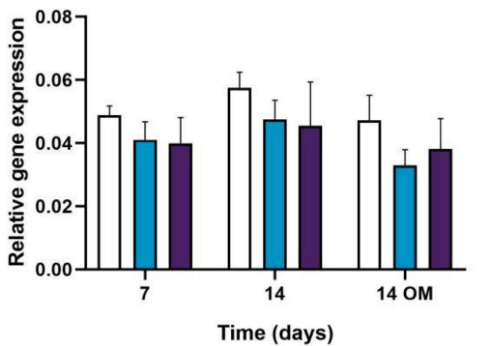

口 CONTROL

PCL

PCL/B-TCP

F

口 CONTROL

$\square \mathrm{PCL}$

DCL/ $\beta$-TCP

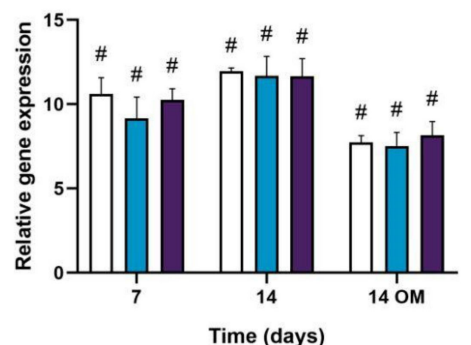

口 CONTROL

$\square \mathrm{PCL}$

PCL/B-TCP

CONTROL

$\square \mathrm{PCL}$

- PCL/ $\beta-T C P$

Figure 10. Quantitative real-time polymerase chain reaction results of osteogenic markers after 7 and 14 days of culture. The results are expressed as mean $\pm \mathrm{SD}$. " Significant differences between the marked group at different time periods $(p>0.05)$. No significant differences were observed between the groups in the same time period. (A) ALPL, alkaline phosphatase; (B) COL1A1, collagen type I; (C) RUNX2, runt-related transcription factor 2; (D) BGLAP, osteocalcin; (E) IBSP, integrin-binding sialoprotein; (F) SPARC, osteonectin; (G) SPP1, osteopontin.

\section{Materials and Methods}

\subsection{Fabrication of Polymer-Based Porous 3D-Printed Scaffolds}

\subsubsection{Preparation of PCL Filaments Coated with $\beta$-TCP Microparticles}

The process used for the preparation of the poly ( $\varepsilon$-caprolactone $) / \beta$-TCP composite filaments, labeled as PCL/ $\beta$-TCP, is described herein. Briefly, PCL (MW $50 \mathrm{kD}$ ) filaments of $1.75 \mathrm{~mm}$ in diameter and $150 \mathrm{~mm}$ in length were heated at $65^{\circ} \mathrm{C}$ in hot water (bain-Marie) until the filament became flexible and changed its aspect from opaque white to completely 
transparent. After this, the filament was coated manually bearing on a surface dusted with copious amounts of $\beta$-TCP powder previously mortared and sieved at $125 \mu \mathrm{m}$. The collected coated filaments were dried at room temperature (RT) for $30 \mathrm{~min}$ before being fed into the printer extruder. It is worth mentioning that both the PCL (uncoated) and $\mathrm{PCL} / \beta$-TCP filaments were weighed in order to estimate the final $\beta$-TCP microparticle concentration of $5 \mathrm{wt} \%$. The average filament diameter was calculated from at least 20 measurements performed on different optical images acquired with a stereomicroscope.

3.1.2. Design and Printing of 3D Scaffolds with Controlled Porosity Using the Fused Deposition Modeling (FDM) Method

The scaffolds were designed with the software REGEMAT 3D Designer v1.4.4 and manufactured by the fused deposition modeling (FDM-3D) method using a REGEMAT 3D Bio V1 ${ }^{\circledR}$ bioprinter (REG4Life, REGEMAT 3D, Granada, Spain) equipped with a glass bed and a $0.4 \mathrm{~mm}$ diameter nozzle (Figure 11A). Both the PCL and PCL/ $\beta$-TCP scaffolds dimensions were set to $1.50 \times 20 \times 20 \mathrm{~mm}$ (height $\times$ width $\times$ length) $($ Figure $11 \mathrm{~B}, \mathrm{C})$ and printed using the same parameters (infill speed of $11 \mathrm{~mm} / \mathrm{s}$, layer height of $0.25 \mathrm{~mm}$, pore size of $200 \mu \mathrm{m}$, and printing temperature of $160^{\circ} \mathrm{C}$ ). The number of perimeters and solid bottom/top layers was set to 0 , allowing to obtain scaffolds with interconnected and open porosity. In order to enhance the reproducibility of the experiments and to reduce the variability between the samples, an $8 \mathrm{~mm}$ biopsy punch was used to prepare defined and reproducible scaffolds (Figure 11D), obtaining four disk-shaped scaffolds of $8 \times 1.5 \mathrm{~mm}$ (diameter $\times$ height) per printed scaffold (Figure 11E), which complies with the recognized international standard ISO/FDIS 23317 [88].

A

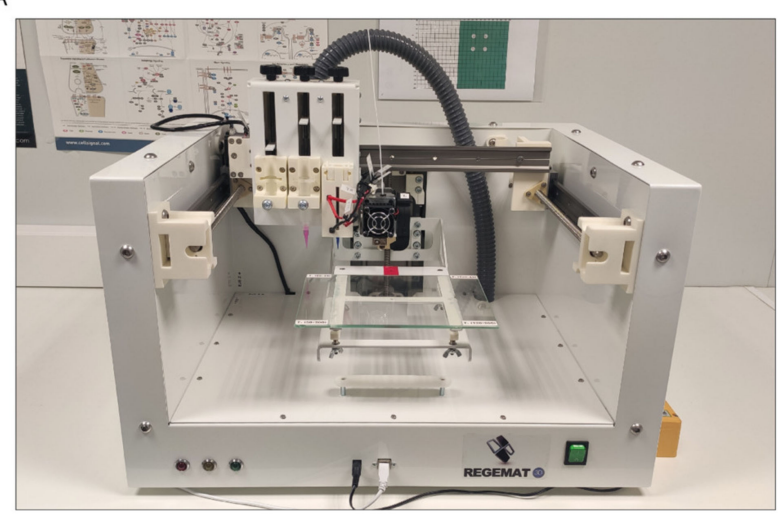

B

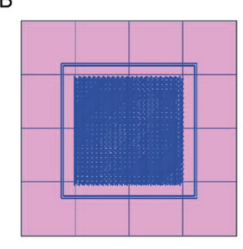

D

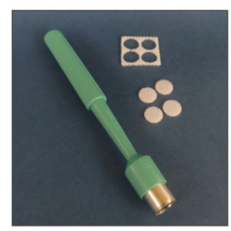

C

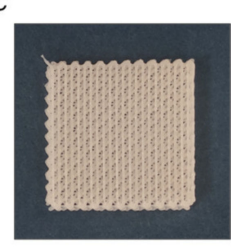

$\mathrm{E}$

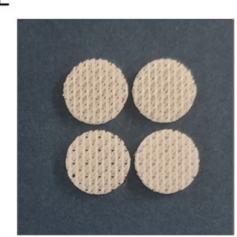

Figure 11. (A) REGEMAT 3D Bio V $1{ }^{\circledR}$ bioprinter, (B) scaffold design with REGEMAT 3D Designer v1.4.4, (C) 3D-printed scaffolds of $1.50 \times 20 \times 20 \mathrm{~mm}$ (height $\times$ width $\times$ length), (D) disk obtention using a $8 \mathrm{~mm}$ biopsy punch, and (E) disk-shaped scaffolds of $8 \times 1.5 \mathrm{~mm}$ (diameter $\times$ height).

Then, the scaffolds were rinsed with distilled water in an orbital shaker for $30 \mathrm{~min}$ at $250 \mathrm{rpm}$ to remove any undesired dust contamination before being sterilized with a pulsed light system XeMaticA-Basic-1L (Steribeam, Kehl, Germany). The latter produces pulses ranging from infrared (IR) to ultraviolet (UV) light with $21 \%$ of UV content [89]. The effectiveness of the method was verified by incubating the samples for five days at $37^{\circ} \mathrm{C}$ in test tubes containing $7 \mathrm{~mL}$ of sterile Tryptic Soy Broth (\#T8907; Sigma-Aldrich, Saint Louis, MO, USA). This methodology is widely used for detecting the presence of microorganisms.

\subsection{Characterization of the Composite Filaments and the 3D-Printed Scaffolds}

3.2.1. Morphological Characterization and Microanalysis of the Filaments and the 3D Scaffolds Scanning Electron Microscopy and Energy-Dispersive X-ray Analysis (SEM-EDX)

Morphological characterization of the filaments and the 3D-printed scaffolds was carried out by means of a digital camera (Axiocam 305 color) coupled to an optical microscope (Zeiss 415510), scanning electron microscopy (SEM; model JEOL-6100 (JEOL Ltd., Tokyo, Japan)), and energy dispersive X-ray spectroscopy (EDX; Oxford INCA (Oxford 
Instruments plc., Abington, Oxfordshire, U.K.). For SEM analysis, the samples were coated with gold, while for EDX analysis, they were carbon-coated to avoid spectrum overlaps with other elements.

Micro-Computed Tomography $(\mu \mathrm{CT})$ Scaffold Imaging: Porosity and $\beta$-TCP Particle Distribution

The scaffold porosity and the distribution of the $\beta$-TCP particles in the scaffold were detected using a Quantum GX2 micro-CT imaging system (PerkinElmer, Hopkinton, MA, USA) at a voxel size of $72 \mu \mathrm{m}$. Typically, three samples randomly selected were placed on a $35 \mathrm{~mm}$ diameter object bed. A complete scan (scanning parameters: energy $=90 \mathrm{kV}$; intensity $=88 \mu \mathrm{A}$ ) was then performed. The scanned microstructural images were reconstructed using Invesalius 3.1 software $\left({ }^{(} 2007-2017\right.$, Center for Information Technology Renato Archer CTI). The total porosity, pore size, and open porosity of each scaffold were analyzed. In order to obtain the total porosity $p$, the scaffold volume $\mathrm{V}_{\mathrm{S}}$ was compared to the theoretical volume of the cylinder $\mathrm{V}_{\mathrm{T}}$ using Equation (1) [10]:

$$
p=1-\left(\mathrm{V}_{\mathrm{S}} / \mathrm{V}_{\mathrm{T}}\right)
$$

\subsubsection{Protein Adhesion: Coomassie Brilliant Blue Test}

The Coomassie Brilliant Blue test was used to determine protein adsorption on the surface of both the PCL and PCL/ $\beta$-TCP scaffolds. First, the scaffolds were immersed for $30 \mathrm{~min}$ in fetal bovine serum (FBS; \#F7524, Sigma-Aldrich, Saint Louis, MO, USA) to allow protein adhesion. Then, the excess solution was removed and the scaffolds were left to dry in an oven at $37^{\circ} \mathrm{C}$ for $45 \mathrm{~min}$. After drying, the scaffolds were fixed with $4 \%$ paraformaldehyde in PBS for $15 \mathrm{~min}$ and immersed for $30 \mathrm{~min}$ in the Coomassie staining solution, which was prepared according to the manufacturer's instructions (Coomassie Brilliant Blue R-250 Dye, \#20278; Thermo Fisher, Rockford, IL, USA). Finally, the scaffolds were rinsed three times with a destaining solution containing methanol/acetic acid/distilled water $(40 / 10 / 50, \% v / v / v)$.

\subsubsection{In Vitro Degradation Kinetics}

Scaffold degradation was assessed in vitro by measuring the weight loss of scaffolds. Typically, polymeric scaffolds were weighed and subsequently immersed in $2 \mathrm{~mL}$ of complete GM (DMEM) in 12-well plates, incubated at $37{ }^{\circ} \mathrm{C}$, in a $5 \% \mathrm{CO}_{2}$ atmosphere with 95\% relative humidity, for different time periods of $1,3,7,14,21$, and 28 days. Then, scaffolds were recovered from the medium, rinsed with deionized water, dried at $37^{\circ} \mathrm{C}$ overnight, and re-weighed. The weight loss (WL) was calculated by applying the following equation:

$$
\mathrm{WL} \%=\left[\left(\mathrm{W}_{0}-\mathrm{W}_{\mathrm{d}}\right) / \mathrm{W}_{0}\right] \times 100
$$

where $W_{0}$ and $W_{d}$ indicate the weight of the scaffold before and after the scheduled immersion time, respectively. Degradation experiments were performed, at least in triplicate, and each measurement was performed six times to obtain appropriate statistics.

\subsection{Isolation, Characterization and Culture of Adult Human Bone Marrow-Derived Mesenchymal Stem Cells (ah-BM-MSCs)}

The ah-BM-MSCs were isolated and cultured as previously described [90,91] and characterized in accordance with the criteria established by the International Society for Cell Therapy (ISCT) [92] (data not shown). Briefly, three healthy patients scheduled for elective orthopedic surgery were recruited for this study. Informed consent was obtained from each of them. Bone marrow was collected by percutaneous direct aspiration from the iliac crest. The mononuclear cells were then separated from the bone marrow and washed using a SEPAX ${ }^{\circledR}$ S-100 device (Biosafe, Eysins, Switzerland). For more details related to the methodology and procedure applied, cell isolation, culture, and expansion of ah-BM-MSCs, please refer to previous publications [90,91]. After determining nucleated cells viability with trypan blue solution (\#T8154; Sigma-Aldrich, Saint Louis, MO, USA) for 
initial expansion, the harvested cells were seeded at a density of $3.75 \times 10^{5} \mathrm{~mL}$ in a $75 \mathrm{~cm}^{2}$ tissue culture flask (Biofil ${ }^{\circledR}$ ) with $10 \mathrm{~mL}$ of basic growth culture medium (GM) consisting of Dulbecco's Minimal Essential Medium (DMEM) (\#31885-023; Gibco, Bleiswijk, the Netherlands) incorporating 10\% $(v / v)$ inactivated fetal bovine serum (FBS) (\#F7524, SigmaAldrich, Saint Louis, MO, USA), $100 \mathrm{U} / \mathrm{mL}$ of penicillin, and $100 \mathrm{\mu g} / \mathrm{mL}$ of streptomycin (\#P4333, Sigma-Aldrich, Saint Louis, MO, USA), and then incubated at $37{ }^{\circ} \mathrm{C}$ in a $5 \%$ $\mathrm{CO}_{2}$ atmosphere with $95 \%$ of relative humidity. After seven days, the culture medium was renewed, thus eliminating the non-adherent cells, including some hematopoietic cells, facilitating the identification and selection of the attached cells [93]. When 80-90\% confluence was reached, cells were treated with $0.25 \% w / v$ trypsin/EDTA (\#T4049, SigmaAldrich, Saint Louis, MO, USA) in phosphate-buffered saline (PBS, pH 7.4) for $5 \mathrm{~min}$. The collected cells were then subcultured at a 1:3 ratio and expanded for future use. Passages 3 and 4 (P3-P4) were trypsinized and collected to be used in all subsequent in vitro assays.

All biological experiments were in full compliance with regulatory guidelines, and the experimental protocol was ethically reviewed and approved by the Institutional Ethics Committee of UCAM-Universidad Católica de Murcia (Authorized No CE051904) UCAM ethics committee (CE $n^{\circ}$ 052114).

\subsection{1. ah-BM-MSC Characterization}

Before performing the in vitro assays, the purity of the ah-BM-MSCs populations was assessed by flow cytometry (Beckman Dickinson \& Co., Franklin Lakes, NJ, USA; Software Navios). In order to characterize the cells, a pool of $a$-BM-MSCs detached from different flasks was labeled with an MSC Phenotyping Kit (\#130-095-198, Miltenyi Biotec, BergischGladbach, Germany) and PE Anti-Rat CD44H mouse IgG2A antibody (R\&D Systems), in order to quantify the expression of CD73, CD90, CD105, and CD44 markers.

\subsubsection{Cell Seeding Methods}

Prior to cell seeding, the scaffolds were conditioned with the culture medium and incubated at $37{ }^{\circ} \mathrm{C}$ in a $5 \% \mathrm{CO}_{2}$ atmosphere with $95 \%$ of relative humidity for $48 \mathrm{~h}$.

For cell adhesion, proliferation, and viability assays, the $a$ h-BM-MSCs were seeded onto the top of the PCL and PCL/ $\beta$-TCP scaffolds at a density of $5 \times 10^{4} \mathrm{cells} \mathrm{cm}^{-2}$ in 48-well plates, taking as a positive control cells seeded onto tissue culture-treated polystyrene wells (TCPS; Sigma-Aldrich, Corning, NY, USA). For the cellular metabolic activity assay (AlamarBlue ${ }^{\circledR}$ Assay), the scaffolds were rigorously changed to a new 48 wellplate $24 \mathrm{~h}$ after seeding, in order to quantify solely the metabolic activity of the cells growing on the scaffolds. At this time, the cells adhered to the bottom of the polystyrene wells were counted and discarded. The mean total count of cells adhered to the bottom of the well plate was $2 \times 10^{4}$ cells cm $\mathrm{cm}^{-2}$, giving an approximate value of $3 \times 10^{4}$ cells adhered to the scaffold.

To perform osteogenic differentiation studies, the scaffolds were placed in $0.4 \mu \mathrm{m}$ pore culture well inserts (Falcon ${ }^{\circledR}$ ) and the ah-BM-MSCs were seeded at the bottom of the wells at a density of $5 \times 10^{3}$ cells cm$~^{-2}$. Cells seeded onto tissue culture-treated polystyrene (TCP) wells were taken as a positive control. From day 7 , a set of at least three plates initially cultured in growth medium (GM) were replaced by osteogenic differentiation medium (OM) (OsteoMAX-XF ${ }^{\mathrm{TM}}$ Differentiation Medium; \#SCM121, Sigma-Aldrich, Saint Louis, $\mathrm{MO}, \mathrm{USA}$ ). Thus, the cellular differentiation induced by all of the scaffolds researched in the present study growing either on GM and OM were characterized in order to assess their effectiveness. The media were changed twice a week for all of the experiments performed.

\subsection{Cell Viability, Adhesion, and Proliferation Assays}

\subsubsection{Cytotoxicity Assay}

The viability of $a h$-BM-MSCs was evaluated using a resazurin-based cell viability assay (AlamarBlue ${ }^{\circledR}$; \#DAL1100, Invitrogen, Carlsbad, CA, USA) on days 1 and 3 after seeding. Briefly, at different time periods of the study, fresh medium $(500 \mu \mathrm{L})$ containing 
$10 \%(v / v)$ AlamarBlue ${ }^{\circledR}$ reagent was added to each well and incubated at $37^{\circ} \mathrm{C}$ in a $5 \%$ $\mathrm{CO}_{2}$ atmosphere with $95 \%$ of relative humidity for $4 \mathrm{~h}$. During this time, the culture plate was wrapped with aluminum foil in order to provide a dark environment. Then, $150 \mu \mathrm{L}$ aliquots of each well were transferred to a black-walled 96-well plate and fluorescence was measured with a Synergy MX ultraviolet-visible (UV-Vis) spectrophotometer (Bio Tek Instruments Inc., Winooski, VT, USA) at excitation and emission wavelengths of 530 and $590 \mathrm{~nm}$, respectively.

\subsubsection{Cellular Metabolic Activity Assay}

AlamarBlue ${ }^{\circledR}$ was used according to the manufacturer's instructions to assess the metabolic activity of the ah-BM-MSCs on days 1,3, 7, and 14 after seeding. In this assay, we only evaluated the metabolic activity of the cells adhered to the scaffolds (cells growing on the well plate are counted and discarded). At each time period of the study, the fluorescence was measured with a Synergy MX ultraviolet-visible (UV-Vis) spectrophotometer (Bio Tek Instruments Inc., Winooski, VT, USA) at excitation and emission wavelengths of 530 and $590 \mathrm{~nm}$, respectively.

\subsection{Osteoblastic Differentiation Assays}

\subsubsection{Alkaline Phosphatase (ALP) Activity}

The ALP activity of the $a h$-BM-MSCs was assessed at 7 and 14 days after seeding using an Alkaline Phosphatase Detection Kit (\#SCR004, Merck Millipore, Billerica, MA, USA). At each time period of the study, cells were detached and an aliquot of $2 \times 10^{4}$ cells (per sample) was treated following the manufacturer's instructions in order to quantify the hydrolysis of p-nitrophenyl phosphate into phosphate and p-nitrophenol. The reaction affords a yellow-colored by-product that is proportional to the amount of ALP present within the reaction. At each time period of the study, the absorbance was measured at a wavelength of $405 \mathrm{~nm}$ in a Synergy MX ultraviolet-visible (UV-Vis) spectrophotometer (Bio Tek Instruments Inc., Winooski, VT, USA).

\subsubsection{In Vitro Mineralization of Alizarin Red Solution (ARS) Staining}

The in vitro mineralization was evaluated by the specific binding of Alizarin Red Solution (ARS) staining to calcium deposits at 7 and 14 days after seeding using an Osteogenesis Assay Kit (\#ECM815; Millipore, Billerica, MA, USA). Briefly, at each time period of the study, the ah-BM-MSCs were stained with ARS and visualized using an optical microscope (Motic AE2000, Shimadzu Corp., Kyoto, Japan). Then, to quantify matrix mineralization, the samples were treated following the manufacturer's instructions, and the optical density (OD) at $405 \mathrm{~nm}$ was measured in a Synergy MX ultraviolet-visible (UV-Vis) spectrophotometer (Bio Tek Instruments Inc., Winooski, VT, USA).

3.5.3. Monitoring Surface Markers in the Cells Seeded on the Scaffolds: Cluster of Differentiation (CD)

In order to characterize the ah-BM-MSCs, quantification of cell surface markers CD73, CD90, CD105 was performed by flow cytometry (Beckman Dickinson \& Co., Franklin Lakes, NJ, USA; Software Navios). First, the cells were detached with TrypLE ${ }^{\mathrm{TM}}$ Select Enzyme (1X) (\#11598846, Gibco, Bleiswijk, the Netherlands) and collected, using $2 \times 10^{5}$ cells for each experimental condition. Then, the cells were washed with PBS and labeled with an MSC Phenotyping Kit (\#130-095-198, Miltenyi Biotec, Bergisch-Gladbach, Germany), consisting of the following fluorochromes: Allophycocyanin (APC) conjugated with CD73, fluorescein isothiocyanate (FITC) conjugated to CD90, phycoerythrin (PE) conjugated to CD105, and peridinin-chlorophyll cy5.5 conjugated with CD14/CD20/CD34/CD45. Additionally, a test tube containing cells labeled with the cocktail isotype was used as a control. To check cell viability, $100 \mu \mathrm{L}$ of the binding buffer $\left(1: 10\right.$ in $\left.\mathrm{H}_{2} \mathrm{O}\right), 5 \mu \mathrm{L}$ of Annexin $\mathrm{V}$ antibody, and $5 \mu \mathrm{L}$ of propidium iodide (IP) were added to a tube labeled as Annexin V (Immuno Step). 
All of the test tubes were kept at $4{ }^{\circ} \mathrm{C}$ (in ice) for $15 \mathrm{~min}$ in a dark environment, and washed with $1000 \mu \mathrm{L}$ of PBS EDTA, except for the Annexin V tube, which was washed with a binding buffer. Then, the tubes were centrifuged $\left(300 \times \mathrm{g}, 10 \mathrm{~min}, 4{ }^{\circ} \mathrm{C}\right)$ and the supernatant was discarded. Finally, the labeled pellet was resuspended with $500 \mu \mathrm{L}$ of PBS/EDTA and the samples were analyzed by flow cytometry.

3.5.4. Osteogenic Gene Expression: Quantitative Real-Time Polymerase Chain Reaction (qRT-PCR) Assay

qRT-PCR assay was performed to analyze the expression of alkaline phosphatase (ALPL), collagen type I (COL1A1), runt-related transcription factor 2 (RUNX2), osteocalcin (BGLAP), integrin-binding sialoprotein (IBSP), osteonectin (SPARC), and osteopontin (SPP1). The total RNA was extracted from cells using an RNAqueous Micro Kit (Invitrogen by Thermo Fisher Scientific, Waltham, MA, USA) according to the manufacturer's instructions, followed by reverse transcription of mRNA with an iScript cDNA Synthesis Kit (Bio-Rad). The quantitative PCR was performed using SYBR Premix ExTaq (Takara) in QuantStudio 5 (Applied Biosystems). Specific primers for mRNA were purchased from Qiagen (QuantiTech Primer Assays, Hilden, Germany). All measurements were carried out at least in triplicate. The $\mathrm{Ct}$ values were converted to relative quantification using the $2 \Delta \mathrm{Ct}$ method by normalizing to glyceraldehyde-3-phosphate dehydrogenase (GAPDH) and hypoxanthine phosphoribosyltransferase 1 (HPRT1) (Qiagen, Hilden, Germany).

\subsection{Statistic}

All data are represented as the mean $\pm \mathrm{SD}$. The statistical significance was determined by a two-way ANOVA using GraphPrism 9.0.1 (GraphPad Software Inc., San Diego, CA, USA) for Windows. Comparisons between groups were evaluated with $t$-tests, with the significance level being $p<0.05$.

\section{Conclusions}

To conclude, in the present work, we presented an innovative strategy of combining polymers and biofriendly ceramics as a platform for bone tissue engineering biomaterials design. We introduced a novel route to fabricate hybrid 3D-printed porous composite scaffolds with open and interconnected porosity based on poly( $\varepsilon$-caprolactone) (PCL) and $\beta$-tricalcium phosphate $(\beta$-TCP) microparticles. We studied in detail their influence in the process of adhesion, proliferation, and osteoblastic differentiation of multipotent adult human bone marrow mesenchymal stem cells (ah-BM-MSCs). We demonstrated their biological response, bioactivity, and biocompatibility via primary mesenchymal stem cell cultures by studying their effects on cytotoxicity (viability) and extracellular matrix production. The mineralization and alkaline phosphatase (ALP) assays revealed that osteogenic differentiation of the $a h$-BM-MSCs increased in the presence of the 3D-printed PCL/ $\beta$-TCP scaffolds if compared to both the control group and the native PCL scaffolds, which demonstrates the effective interactions between the $\beta$-TCP microparticles and cells. The latter was also confirmed by quantifying the percentage of mesenchymal marker loss (flow cytometry) and monitoring the gene expression levels (qRT-PCR) of most of the proteins involved in the ossification process. The calcium ions released are probably the main responsibility of metabolic activity and cellular differentiation. Our findings suggest that similar bio-inspired hybrid composite materials would be excellent candidates for osteoinductive and osteogenic medical-grade biomaterials.

Supplementary Materials: The following are available online at https:/ / www.mdpi.com/article/ 10.3390/ijms222011216/s1, Figure S1: SEM micrographs of the (A) native PCL and (B) PCL/ $\beta$-TCP filaments. (C) Image of both filaments taken with a stereomicroscope at $3 \mathrm{X}$ magnification. The $\beta$-TCP microparticles were stained with nigrosine to get clear and highly defined images. (D) Micrograph showing a magnification of the $\beta$-TCP microparticles coating the filament and (E) its corresponding EDX spectrum. The researched area is depicted as a yellow square. 
Author Contributions: Conceptualization, I.L.-G., C.Z.-L. and L.M.-O.; methodology, I.L.-G., L.M.-O. and J.A.G.-H.; software, I.L.-G.; investigation and validation, I.L.-G., C.Z.-L., L.M.-O., J.A.G.-H., E.T.B. and M.I.S.-L.; formal analysis, I.L.-G., C.Z.-L. and L.M.-O.; data curation, L.M.-O., C.Z.-L. and J.A.G.-H.; writing-original draft preparation, I.L.-G., C.Z.-L., J.A.G.-H. and L.M.-O.; writing-review and editing, I.L.-G., C.Z.-L., L.M.-O., J.A.G.-H., E.T.B. and M.I.S.-L.; visualization, I.L.-G., C.Z.-L. and L.M.-O.; supervision, L.M.-O.; project administration, I.L.-G. and C.Z.-L. All authors have read and agreed to the published version of the manuscript.

Funding: This research received no external funding.

Institutional Review Board Statement: This study was conducted according to the guidelines of the Declaration of Helsinki and approved by the Institutional Ethics Committee of UCAM-Universidad Católica de Murcia (Authorized No CE051904) and UCAM ethics committee (CE nº52114).

Informed Consent Statement: Informed consent was obtained from all subjects involved in the study.

Data Availability Statement: The data presented in this study have been disclosed in the main text.

Acknowledgments: The authors of this study would like to thank the Genomic Platform of IMIBArrixaca, Murcia (Spain), and especially Alberto Baroja-Mazo for his invaluable technical assistance.

Conflicts of Interest: The authors declare no conflict of interest.

\section{References}

1. Rodrigues, M.T.; Gonçalves, A.I.; Babo, P.S.; Gomez-Florit, M.; Reis, R.L.; Gomes, M.E. Bioinspired materials and tissue engineering approaches applied to the regeneration of musculoskeletal tissues. In Engineering Strategies for Regenerative Medicine; Academic Press: Cambridge, MA, USA, 2020; pp. 73-105.

2. Diaz-Arca, A.; Ros-Tarraga, P.; Tome, M.J.M.; De Aza, A.H.; Meseguer-Olmo, L.; Mazon, P.; De Aza, P.N. Micro-/Nano-Structured Ceramic Scaffolds That Mimic Natural Cancellous Bone. Materials 2021, 14, 1439. [CrossRef] [PubMed]

3. Li, X.; Wang, L.; Fan, Y.; Feng, Q.; Cui, F.Z.; Watari, F. Nanostructured scaffolds for bone tissue engineering. J. Biomed. Mater. Res. A 2013, 101, 2424-2435. [CrossRef]

4. Baino, F.; Novajra, G.; Vitale-Brovarone, C. Bioceramics and Scaffolds: A Winning Combination for Tissue Engineering. Front. Bioeng. Biotechnol. 2015, 3, 202. [CrossRef] [PubMed]

5. Ribas, R.G.; Schatkoski, V.M.; Montanheiro, T.L.D.A.; de Menezes, B.R.C.; Stegemann, C.; Leite, D.M.G.; Thim, G.P. Current advances in bone tissue engineering concerning ceramic and bioglass scaffolds: A review. Ceram. Int. 2019, 45, 21051-21061. [CrossRef]

6. Boyan, B.D.; Hummert, T.W.; Dean, D.D.; Schwartz, Z. Role of material surfaces in regulating bone and cartilage cell response. Biomaterials 1996, 17, 137-146. [CrossRef]

7. Bosetti, M.; Cannas, M. The effect of bioactive glasses on bone marrow stromal cells differentiation. Biomaterials 2005, 26, 3873-3879. [CrossRef] [PubMed]

8. Wubneh, A.; Tsekoura, E.K.; Ayranci, C.; Uludag, H. Current state of fabrication technologies and materials for bone tissue engineering. Acta Biomater. 2018, 80, 1-30. [CrossRef]

9. Qu, H.; Fu, H.; Han, Z.; Sun, Y. Biomaterials for bone tissue engineering scaffolds: A review. RSC Adv. 2019, 9, $26252-26262$. [CrossRef]

10. Bruyas, A.; Lou, F.; Stahl, A.M.; Gardner, M.; Maloney, W.; Goodman, S.; Yang, Y.P. Systematic characterization of 3D-printed $\mathrm{PCL} / \beta$-TCP scaffolds for biomedical devices and bone tissue engineering: Influence of composition and porosity. J. Mater. Res. 2018, 33, 1948-1959. [CrossRef]

11. López-Álvarez, M.; Rodríguez-Valencia, C.; Serra, J.; González, P. Bio-inspired Ceramics: Promising Scaffolds for Bone Tissue Engineering. Procedia Eng. 2013, 59, 51-58. [CrossRef]

12. Lugo, G.J.; Mazón, P.; De Aza, P.N. Phase transitions in single phase Si-Ca-P-based ceramic under thermal treatment. J. Eur. Ceram. Soc. 2015, 35, 3693-3700. [CrossRef]

13. Puppi, D.; Chiellini, F.; Piras, A.M.; Chiellini, E. Polymeric materials for bone and cartilage repair. Prog. Polym. Sci. 2010, 35, 403-440. [CrossRef]

14. Hild, N.; Schneider, O.D.; Mohn, D.; Luechinger, N.A.; Koehler, F.M.; Hofmann, S.; Vetsch, J.R.; Thimm, B.W.; Muller, R.; Stark, W.J. Two-layer membranes of calcium phosphate/collagen/PLGA nanofibres: In vitro biomineralisation and osteogenic differentiation of human mesenchymal stem cells. Nanoscale 2011, 3, 401-409. [CrossRef]

15. Shi, C.; Yuan, Z.; Han, F.; Zhu, C.; Li, B. Polymeric biomaterials for bone regeneration. Ann. Jt. 2016, 1, 27. [CrossRef]

16. Carrodeguas, R.G.; De Aza, S. $\alpha$-Tricalcium phosphate: Synthesis, properties and biomedical applications. Acta Biomater. 2011, 7, 3536-3546. [CrossRef]

17. Kim, H.W.; Kim, H.E.; Knowles, J.C. Production and Potential of Bioactive Glass Nanofibers as a Next-Generation Biomaterial. Adv. Funct. Mater. 2006, 16, 1529-1535. [CrossRef] 
18. Xie, J.; Blough, E.R.; Wang, C.H. Submicron bioactive glass tubes for bone tissue engineering. Acta Biomater. $2012,8,811-819$. [CrossRef]

19. Yoshimoto, H.; Shin, Y.M.; Terai, H.; Vacanti, J.P. A biodegradable nanofiber scaffold by electrospinning and its potential for bone tissue engineering. Biomaterials 2003, 24, 2077-2082. [CrossRef]

20. Lee, S.; Choi, D.; Shim, J.H.; Nam, W. Efficacy of three-dimensionally printed polycaprolactone/ $\beta$ tricalcium phosphate scaffold on mandibular reconstruction. Sci. Rep. 2020, 10, 4979. [CrossRef] [PubMed]

21. Lee, J.S.; Park, T.H.; Ryu, J.Y.; Kim, D.K.; Oh, E.J.; Kim, H.M.; Shim, J.H.; Yun, W.S.; Huh, J.B.; Moon, S.H.; et al. Osteogenesis of 3D-Printed PCL/TCP/bdECM Scaffold Using Adipose-Derived Stem Cells Aggregates; An Experimental Study in the Canine Mandible. Int. J. Mol. Sci. 2021, 22, 5409. [CrossRef] [PubMed]

22. Lin, H.R.; Yeh, Y.J. Porous alginate/hydroxyapatite composite scaffolds for bone tissue engineering: Preparation, characterization, and in vitro studies. J. Biomed. Mater. Res. B Appl. Biomater. 2004, 71, 52-65. [CrossRef]

23. Turco, G.; Marsich, E.; Bellomo, F.; Semeraro, S.; Donati, I.; Brun, F.; Grandolfo, M.; Accardo, A.; Paoletti, S. Alginate/Hydroxyapatite biocomposite for bone ingrowth: A trabecular structure with high and isotropic connectivity. Biomacromolecules 2009, 10, 1575-1583. [CrossRef]

24. Ravichandran, R.; Venugopal, J.R.; Sundarrajan, S.; Mukherjee, S.; Ramakrishna, S. Precipitation of nanohydroxyapatite on PLLA/PBLG/Collagen nanofibrous structures for the differentiation of adipose derived stem cells to osteogenic lineage. Biomaterials 2012, 33, 846-855. [CrossRef] [PubMed]

25. Ruhe, P.Q.; Hedberg, E.L.; Padron, N.T.; Spauwen, P.H.; Jansen, J.A.; Mikos, A.G. rhBMP-2 release from injectable poly(DLlactic-co-glycolic acid)/calcium-phosphate cement composites. J. Bone Joint Surg. Am. 2003, 85-A (Suppl. 3), 75-81. [CrossRef] [PubMed]

26. Meseguer-Olmo, L.; Bernabeu-Esclapez, A.; Ros-Martinez, E.; Sanchez-Salcedo, S.; Padilla, S.; Martin, A.I.; Vallet-Regi, M.; Clavel-Sainz, M.; Lopez-Prats, F.; Meseguer-Ortiz, C.L. In vitro behaviour of adult mesenchymal stem cells seeded on a bioactive glass ceramic in the $\mathrm{SiO}(2)-\mathrm{CaO}-\mathrm{P}(2) \mathrm{O}(5)$ system. Acta Biomater. 2008, 4, 1104-1113. [CrossRef] [PubMed]

27. LeGeros, R.Z. Properties of osteoconductive biomaterials: Calcium phosphates. Clin. Orthop. Relat. Res. 2002, 395, 81-98. [CrossRef] [PubMed]

28. Burg, K.J.L.; Porter, S.; Kellam, J.F. Biomaterial developments for bone tissue engineering. Biomaterials 2000, 21, 2347-2359. [CrossRef]

29. Wang, Q.; Ye, W.; Ma, Z.; Xie, W.; Zhong, L.; Wang, Y.; Rong, Q. 3D printed PCL/ $\beta$-TCP cross-scale scaffold with high-precision fiber for providing cell growth and forming bones in the pores. Mater. Sci. Eng. C Mater. Biol. Appl. 2021, 127, 112197. [CrossRef]

30. Kumar, P.; Dehiya, B.S.; Sindhu, A. Bioceramics for Hard Tissue Engineering Applications: A Review. Int. J. Appl. Eng. Res. 2018, $13,2744-2752$.

31. Urist, M.R.; Lietze, A.; Dawson, E. Beta-tricalcium phosphate delivery system for bone morphogenetic protein. Clin. Orthop. Relat. Res. 1984, 187, 277-280.

32. Ginebra, M.P.; Traykova, T.; Planell, J.A. Calcium phosphate cements as bone drug delivery systems: A review. J. Control. Release 2006, 113, 102-110. [CrossRef]

33. Li, X.; Xie, J.; Yuan, X.; Xia, Y. Coating electrospun poly(epsilon-caprolactone) fibers with gelatin and calcium phosphate and their use as biomimetic scaffolds for bone tissue engineering. Langmuir 2008, 24, 14145-14150. [CrossRef]

34. Liu, W.; Yeh, Y.C.; Lipner, J.; Xie, J.; Sung, H.W.; Thomopoulos, S.; Xia, Y. Enhancing the stiffness of electrospun nanofiber scaffolds with a controlled surface coating and mineralization. Langmuir 2011, 27, 9088-9093. [CrossRef]

35. Bae, E.B.; Park, K.H.; Shim, J.H.; Chung, H.Y.; Choi, J.W.; Lee, J.J.; Kim, C.H.; Jeon, H.J.; Kang, S.S.; Huh, J.B. Efficacy of rhBMP-2 Loaded PCL/ $\beta$-TCP/bdECM Scaffold Fabricated by 3D Printing Technology on Bone Regeneration. Biomed. Res. Int. 2018, 2018, 2876135. [CrossRef] [PubMed]

36. Perez, R.A.; Kim, H.W.; Ginebra, M.P. Polymeric additives to enhance the functional properties of calcium phosphate cements. J. Tissue Eng. 2012, 3, 2041731412439555. [CrossRef] [PubMed]

37. Ruoslahti, E. Fibronectin in cell adhesion and invasion. Cancer Metastasis Rev. 1984, 3, 43-51. [CrossRef] [PubMed]

38. Bachman, H.; Nicosia, J.; Dysart, M.; Barker, T.H. Utilizing Fibronectin Integrin-Binding Specificity to Control Cellular Responses. Adv. Wound Care 2015, 4, 501-511. [CrossRef]

39. Pirraco, R.P.; Marques, A.P.; Reis, R.L. Cell interactions in bone tissue engineering. J. Cell Mol. Med. 2010, 14, 93-102. [CrossRef]

40. Reichert, J.C.; Wullschleger, M.E.; Cipitria, A.; Lienau, J.; Cheng, T.K.; Schutz, M.A.; Duda, G.N.; Noth, U.; Eulert, J.; Hutmacher, D.W. Custom-made composite scaffolds for segmental defect repair in long bones. Int. Orthop. 2011, 35, 1229-1236. [CrossRef]

41. Shin, Y.M.; Park, J.-S.; Jeong, S.I.; An, S.-J.; Gwon, H.-J.; Lim, Y.-M.; Nho, Y.-C.; Kim, C.-Y. Promotion of human mesenchymal stem cell differentiation on bioresorbable polycaprolactone/biphasic calcium phosphate composite scaffolds for bone tissue engineering. Biotechnol. Bioprocess Eng. 2014, 19, 341-349. [CrossRef]

42. Park, S.H.; Park, S.A.; Kang, Y.G.; Shin, J.W.; Park, Y.S.; Gu, S.R.; Wu, Y.R.; Wei, J.; Shin, J.W. PCL/ $\beta$-TCP Composite Scaffolds Exhibit Positive Osteogenic Differentiation with Mechanical Stimulation. Tissue Eng. Regen. Med. 2017, 14, 349-358. [CrossRef]

43. Yang, D.H.; Heo, G.M.; Park, H.J.; Oh, H.K.; Kook, M.S. Comparative Effectiveness of Surface Functionalized Poly-epsilonCaprolactone Scaffold and $\beta$-TCP Mixed PCL Scaffold for Bone Regeneration. J. Nanosci. Nanotechnol. 2020, 20, 5349-5355. [CrossRef] 
44. Zhu, W.; Ma, X.; Gou, M.; Mei, D.; Zhang, K.; Chen, S. 3D printing of functional biomaterials for tissue engineering. Curr. Opin. Biotechnol. 2016, 40, 103-112. [CrossRef]

45. Chen, M.; Gao, S.; Wang, P.; Li, Y.; Guo, W.; Zhang, Y.; Wang, M.; Xiao, T.; Zhang, Z.; Zhang, X.; et al. The application of electrospinning used in meniscus tissue engineering. J. Biomater. Sci. Polym. Ed. 2018, 29, 461-475. [CrossRef]

46. Izadyari Aghmiuni, A.; Heidari Keshel, S.; Sefat, F.; AkbarzadehKhiyavi, A. Fabrication of 3D hybrid scaffold by combination technique of electrospinning-like and freeze-drying to create mechanotransduction signals and mimic extracellular matrix function of skin. Mater. Sci. Eng. C Mater. Biol. Appl. 2021, 120, 111752. [CrossRef]

47. Chen, W.; Zhou, H.; Tang, M.; Weir, M.D.; Bao, C.; Xu, H.H. Gas-foaming calcium phosphate cement scaffold encapsulating human umbilical cord stem cells. Tissue Eng. Part A 2012, 18, 816-827. [CrossRef]

48. Moroni, L.; de Wijn, J.R.; van Blitterswijk, C.A. 3D fiber-deposited scaffolds for tissue engineering: Influence of pores geometry and architecture on dynamic mechanical properties. Biomaterials 2006, 27, 974-985. [CrossRef] [PubMed]

49. Atala, A.; Yoo, J.J. Essentials of 3D Biofabrication and Translation; Academic Press: Cambridge, MA, USA, 2015.

50. Williams, D.F. The Williams Dictionary of Biomaterials; Liverpool University Press: Liverpool, UK, 1999.

51. Shie, M.Y.; Ding, S.J. Integrin binding and MAPK signal pathways in primary cell responses to surface chemistry of calcium silicate cements. Biomaterials 2013, 34, 6589-6606. [CrossRef] [PubMed]

52. Zhu, X.D.; Fan, H.S.; Zhao, C.Y.; Lu, J.; Ikoma, T.; Tanaka, J.; Zhang, X.D. Competitive adsorption of bovine serum albumin and lysozyme on characterized calcium phosphates by polyacrylamide gel electrophoresis method. J. Mater. Sci. Mater. Med. 2007, 18, 2243-2249. [CrossRef] [PubMed]

53. Hung, C.J.; Hsu, H.I.; Lin, C.C.; Huang, T.H.; Wu, B.C.; Kao, C.T.; Shie, M.Y. The role of integrin $\alpha \mathrm{v}$ in proliferation and differentiation of human dental pulp cell response to calcium silicate cement. J. Endod. 2014, 40, 1802-1809. [CrossRef]

54. Sukanya, V.S.; Mohanan, P.V. Degradation of Poly(epsilon-caprolactone) and bio-interactions with mouse bone marrow mesenchymal stem cells. Colloids Surf. B Biointerfaces 2018, 163, 107-118.

55. Huang, S.H.; Hsu, T.T.; Huang, T.H.; Lin, C.Y.; Shie, M.Y. Fabrication and characterization of polycaprolactone and tricalcium phosphate composites for tissue engineering applications. J. Dent. Sci. 2017, 12, 33-43. [CrossRef] [PubMed]

56. Yeo, A.; Rai, B.; Sju, E.; Cheong, J.J.; Teoh, S.H. The degradation profile of novel, bioresorbable PCL-TCP scaffolds: An in vitro and in vivo study. J. Biomed. Mater. Res. A 2008, 84, 208-218. [CrossRef] [PubMed]

57. Lei, Y.; Rai, B.; Ho, K.H.; Teoh, S.H. In vitro degradation of novel bioactive polycaprolactone-20\% tricalcium phosphate composite scaffolds for bone engineering. Mater. Sci. Eng. C 2007, 27, 293-298. [CrossRef]

58. Pena, J.; Corrales, T.; Izquierdo-Barba, I.; Serrano, M.C.; Portoles, M.T.; Pagani, R.; Vallet-Regi, M. Alkaline-treated poly(epsiloncaprolactone) films: Degradation in the presence or absence of fibroblasts. J. Biomed. Mater. Res. A 2006, 76, 788-797. [CrossRef] [PubMed]

59. Liu, S.; Jin, F.; Lin, K.; Lu, J.; Sun, J.; Chang, J.; Dai, K.; Fan, C. The effect of calcium silicate on in vitro physiochemical properties and in vivo osteogenesis, degradability and bioactivity of porous $\beta$-tricalcium phosphate bioceramics. Biomed. Mater. 2013, 8, 025008. [CrossRef]

60. Khan, A.F.; Saleem, M.; Afzal, A.; Ali, A.; Khan, A.; Khan, A.R. Bioactive behavior of silicon substituted calcium phosphate based bioceramics for bone regeneration. Mater. Sci. Eng. C Mater. Biol. Appl. 2014, 35, 245-252. [CrossRef]

61. Mushahary, D.; Spittler, A.; Kasper, C.; Weber, V.; Charwat, V. Isolation, cultivation, and characterization of human mesenchymal stem cells. Cytometry A 2018, 93, 19-31. [CrossRef]

62. Maxim, M.A.; Soritau, O.; Baciut, M.; Bran, S.; Baciut, G. The role of dental stem cells in regeneration. Clujul Med. 2015, 88, 479-482. [CrossRef]

63. Baghaei, K.; Hashemi, S.M.; Tokhanbigli, S.; Asadi Rad, A.; Assadzadeh-Aghdaei, H.; Sharifian, A.; Zali, M.R. Isolation, differentiation, and characterization of mesenchymal stem cells from human bone marrow. Gastroenterol. Hepatol. Bed Bench 2017, 10, 208-213.

64. Kim, Y.B.; Kim, G. Functionally graded PCL/ $\beta$-TCP biocomposites in a multilayered structure for bone tissue regeneration. Appl. Phys. A 2012, 108, 949-959. [CrossRef]

65. Petit, C.; Tulliani, J.M.; Tadier, S.; Meille, S.; Chevalier, J.; Palmero, P. Novel calcium phosphate/PCL graded samples: Design and development in view of biomedical applications. Mater. Sci. Eng. C Mater. Biol. Appl. 2019, 97, 336-346. [CrossRef] [PubMed]

66. Yuan, B.; Wang, Z.; Zhao, Y.; Tang, Y.; Zhou, S.; Sun, Y.; Chen, X. In Vitro and In Vivo Study of a Novel Nanoscale Demineralized Bone Matrix Coated PCL/ $\beta$-TCP Scaffold for Bone Regeneration. Macromol. Biosci. 2021, 21, e2000336. [CrossRef] [PubMed]

67. Patrício, T.; Domingos, M.; Gloria, A.; Bártolo, P. Characterisation of PCL and PCL/PLA Scaffolds for Tissue Engineering. Procedia CIRP 2013, 5, 110-114. [CrossRef]

68. Dou, Y.; Fa, X.; Gu, Y.; Liang, L.; Wen, J.; Qin, A.; Ou, J. Fabrication and characterization of PVA/CS-PCL/gel multi-scale electrospun scaffold: Simulating extracellular matrix for enhanced cellular infiltration and proliferation. J. Biomater. Sci. Polym. Ed. 2020, 31, 729-746. [CrossRef]

69. Li, Z.; Wu, N.; Cheng, J.; Sun, M.; Yang, P.; Zhao, F.; Zhang, J.; Duan, X.; Fu, X.; Zhang, J.; et al. Biomechanically, structurally and functionally meticulously tailored polycaprolactone/silk fibroin scaffold for meniscus regeneration. Theranostics 2020, 10, 5090-5106. [CrossRef]

70. Kao, C.T.; Lin, C.C.; Chen, Y.W.; Yeh, C.H.; Fang, H.Y.; Shie, M.Y. Poly(dopamine) coating of 3D printed poly(lactic acid) scaffolds for bone tissue engineering. Mater. Sci. Eng. C Mater. Biol. Appl. 2015, 56, 165-173. [CrossRef] 
71. Zernik, J.; Twarog, K.; Upholt, W.B. Regulation of alkaline phosphatase and $\alpha$ 2(I) procollagen synthesis during early intramembranous bone formation in the rat mandible. Differentiation 1990, 44, 207-215. [CrossRef]

72. Fishman, W.H.; Ghosh, N.K. Isoenzymes of Human Alkaline Phosphatase. In Advances in Clinical Chemistry Volume 10; Academic Press: Cambridge, MA, USA, 1967; pp. 255-370.

73. Jansen, J.H.; van der Jagt, O.P.; Punt, B.J.; Verhaar, J.A.; van Leeuwen, J.P.; Weinans, H.; Jahr, H. Stimulation of osteogenic differentiation in human osteoprogenitor cells by pulsed electromagnetic fields: An in vitro study. BMC Musculoskelet. Disord. 2010, 11, 188. [CrossRef]

74. Gao, P.; Zhang, H.; Liu, Y.; Fan, B.; Li, X.; Xiao, X.; Lan, P.; Li, M.; Geng, L.; Liu, D.; et al. Beta-tricalcium phosphate granules improve osteogenesis in vitro and establish innovative osteo-regenerators for bone tissue engineering in vivo. Sci. Rep. 2016, 6, 23367. [CrossRef]

75. Chen, M.; Le, D.Q.; Kjems, J.; Bunger, C.; Lysdahl, H. Improvement of Distribution and Osteogenic Differentiation of Human Mesenchymal Stem Cells by Hyaluronic Acid and $\beta$-Tricalcium Phosphate-Coated Polymeric Scaffold In Vitro. Biores. Open Access 2015, 4, 363-373. [CrossRef] [PubMed]

76. Jensen, J.; Kraft, D.C.; Lysdahl, H.; Foldager, C.B.; Chen, M.; Kristiansen, A.A.; Rolfing, J.H.; Bunger, C.E. Functionalization of polycaprolactone scaffolds with hyaluronic acid and $\beta$-TCP facilitates migration and osteogenic differentiation of human dental pulp stem cells in vitro. Tissue Eng. Part A 2015, 21, 729-739. [CrossRef] [PubMed]

77. Gurel Pekozer, G.; Ramazanoglu, M.; Schlegel, K.A.; Kok, F.N.; Torun Kose, G. Role of STRO-1 sorting of porcine dental germ stem cells in dental stem cell-mediated bone tissue engineering. Artif. Cells Nanomed. Biotechnol. 2018, 46, 607-618. [CrossRef] [PubMed]

78. Mafi, P.; Hindocha, S.; Mafi, R.; Griffin, M.; Khan, W.S. Adult mesenchymal stem cells and cell surface characterization-A systematic review of the literature. Open Orthop. J. 2011, 5 (Suppl. 2), 253-260. [CrossRef] [PubMed]

79. Feng-Juan, L.V.; Tuan, R.S.; Cheung, K.M.; Leung, V.Y. Concise review: The surface markers and identity of human mesenchymal stem cells. Stem Cells 2014, 32, 1408-1419.

80. Viti, F.; Landini, M.; Mezzelani, A.; Petecchia, L.; Milanesi, L.; Scaglione, S. Osteogenic Differentiation of MSC through Calcium Signaling Activation: Transcriptomics and Functional Analysis. PLoS ONE 2016, 11, e0148173. [CrossRef] [PubMed]

81. Rabadan-Ros, R.; Revilla-Nuin, B.; Mazón, P.; Aznar-Cervantes, S.; Ros-Tarraga, P.; De Aza, P.N.; Meseguer-Olmo, L. Impact of a Porous Si-Ca-P Monophasic Ceramic on Variation of Osteogenesis-Related Gene Expression of Adult Human Mesenchymal Stem Cells. Appl. Sci. 2018, 8, 46 .

82. Karsenty, G.; Ducy, P.; Starbuck, M.; Priemel, M.; Shen, J.; Geoffroy, V.; Amling, M. Cbfa1 as a regulator of osteoblast differentiation and function. Bone 1999, 25, 107-108. [CrossRef]

83. Ducy, P. CBFA1: A molecular switch in osteoblast biology. Dev. Dyn. 2000, 219, 461-471. [CrossRef]

84. Ziros, P.G.; Basdra, E.K.; Papavassiliou, A.G. Runx2: Of bone and stretch. Int. J. Biochem. Cell Biol. 2008, 40, 1659-1663. [CrossRef]

85. Marie, P.J. Transcription factors controlling osteoblastogenesis. Arch. Biochem. Biophys. 2008, 473, 98-105. [CrossRef]

86. Ducy, P.; Zhang, R.; Geoffroy, V.; Ridall, A.L.; Karsenty, G. Osf2/Cbfa1: A Transcriptional Activator of Osteoblast Differentiation. Cell 1997, 89, 747-754. [CrossRef]

87. Franceschi, R.T.; Xiao, G. Regulation of the osteoblast-specific transcription factor, Runx2: Responsiveness to multiple signal transduction pathways. J. Cell Biochem. 2003, 88, 446-454. [CrossRef] [PubMed]

88. International Organization for Standardization [ISO]. Implants for Surgery—In Vitro Evaluation for Apatite-Forming Ability of Implant Materials; ISO/FDIS Standard No. 23317; ISO: London, UK, 2014.

89. Cudemos, E.; Izquier, A.; Medina-Martínez, M.S.; Gómez-López, V.M. Effects of shading and growth phase on the microbial inactivation by pulsed light. Czech J. Food Sci. 2013, 31, 189-193. [CrossRef]

90. De Aza, P.N.; Garcia-Bernal, D.; Cragnolini, F.; Velasquez, P.; Meseguer-Olmo, L. The effects of Ca2SiO4-Ca3(PO4)2 ceramics on adult human mesenchymal stem cell viability, adhesion, proliferation, differentiation and function. Mater. Sci. Eng. C Mater. Biol. Appl. 2013, 33, 4009-4020. [CrossRef] [PubMed]

91. Meseguer-Olmo, L.; Aznar-Cervantes, S.; Mazon, P.; De Aza, P.N. “In vitro" behaviour of adult mesenchymal stem cells of human bone marrow origin seeded on a novel bioactive ceramics in the $\mathrm{Ca}_{2} \mathrm{SiO}_{4}-\mathrm{Ca}_{3}\left(\mathrm{PO}_{4}\right)_{2}$ system. J. Mater. Sci. Mater. Med. 2012, 23, 3003-3014. [CrossRef] [PubMed]

92. Dominici, M.; Le Blanc, K.; Mueller, I.; Slaper-Cortenbach, I.; Marini, F.; Krause, D.; Deans, R.; Keating, A.; Prockop, D.; Horwitz, E. Minimal criteria for defining multipotent mesenchymal stromal cells. The International Society for Cellular Therapy position statement. Cytotherapy 2006, 8, 315-317. [CrossRef] [PubMed]

93. Mauney, J.R.; Blumberg, J.; Pirun, M.; Volloch, V.; Vunjak-Novakovic, G.; Kaplan, D.L. Osteogenic differentiation of human bone marrow stromal cells on partially demineralized bone scaffolds in vitro. Tissue Eng. 2004, 10, 81-92. [CrossRef] [PubMed] 